\title{
Seismicity in the Pannonian Region - earthquake data
}

\author{
L. Tóth, P. Mónus, T. Zsíros, and M. Kiszely \\ Seismological Observatory, Hungarian Academy of Sciences Meredek u. 18, H-1112 Budapest, Hungary
}

Received: 2 May 2000 - Accepted: 16 July 2001

\begin{abstract}
A comprehensive earthquake catalogue has been compiled, listing historical and instrumentally recorded earthquakes throughout the Pannonian Region bounded by 44.0-50.0 N latitude and 13.0-28.0 E longitude. The catalogue contains more than 20000 events ranging in date from $456 \mathrm{AD}$ to 1998 and is considered to be complete for earthquakes larger than M 6.4 since 1500, for earthquakes larger than M 4.7 since 1800 and for magnitudes greater than 3.5 since 1880. In combination with the stress data derived from 190 focal mechanism solutions for individual earthquakes these data provide a relatively strong basis for evaluating seismic sources and seismotectonic models both within and surrounding the Pannonian Basin. The most active parts of the area are the Carpathian and Dinaric tectonic belt and the Vrancea region in the Southeast Carpathians. Seismicity in the Pannonian Basin is more moderate compared to the peripheral areas, however distribution of the total seismic energy release indicates current deformation in the basin area as well. Shallow hypocental depth within the top $20 \mathrm{~km}$ of the earth's crust is principal in the entire region except for the Vrancea zone where intermediate depth seismicity (from 70 to $160 \mathrm{~km}$ ) is governing. In the Pannonian Basin area the majority of events occur between 6 and $15 \mathrm{~km}$. Focal mechanism solutions show that strike-slip and thrust faulting are almost exclusive in the Southern Alps and in the Dinarides. In the Eastern Alps and Western Carpathians focal mechanism solutions present exclusively strike-slip character. In the Pannonian Basin, thrust and strike-slip faulting seem to be dominant, while earthquakes in the Vrancea area occur in a compressive regime with thrust tectonics.
\end{abstract}

\section{Introduction}

Within plate tectonic theory, deformation and consequently seismicity is concentrated along the boundaries of rigid plates. For that reason seismicity is one piece of information essential for understanding current tectonics. On the other hand, the extension of plate tectonics to a regional or

Correspondence to: L. Tóth (laszlo@ seismology.hu) local scale is a more complicated task and should be performed with great care. Not only because almost $10 \%$ of all earthquakes occur within plate interiors globally, but also as plates continue to move, plate boundaries change over geologic time and weakened boundary regions become part of the interiors of the plates. These zones of weakness within the continents can cause earthquakes, either in response to stresses that originate at the edges of the plate or in response to local gravitational stresses.

Nevertheless, the study of the recent tectonics requires input data from the seismic activity of the area: if existing tectonic features are active in the present, or were active in the recent past, this necessarily should be reflected in current seismicity. Earthquakes represent the sudden release of slowly accumulated strain energy and hence provide direct evidence of active tectonic processes. However, low and moderate seismicity at intraplate areas generally precludes reliable statistical correlation between epicenters and geological features.

The Pannonian Basin and surrounding orogens (referred as "Pannonian Region") are located in the northern sector of the central Mediterranean region. The Pannonian Basin is bounded on the north to the east by the Carpathian mountain belt, on the south by the Dinarides mountain belt and on the west by the Eastern Alps. The area is tectonically rather complicated and has been studied intensively over the last twenty years. Development of the Carpathian mountain belt and the Pannonian Basin is attributed to collision between the Eurasian Plate and the African Plate between the Paleocene and Middle-Late Miocene (Horváth, 1984, 1988; Royden, 1988). Different authors basically agree that present-day deformation in the Pannonian Basin system is controlled by the northward movement and counter-clockwise rotation of the Adriatic microplate relative to Europe (Bada, 1999; Bada et al., 1998, 1999; Gerner et al., 1999).

The aim of this study is to document the latest results in understanding the seismicity of the Pannonian Region, based on available earthquake-related information, epicentral and depth distribution, energy release, magnitude recurrence and stress data derived from focal mechanism solutions. 


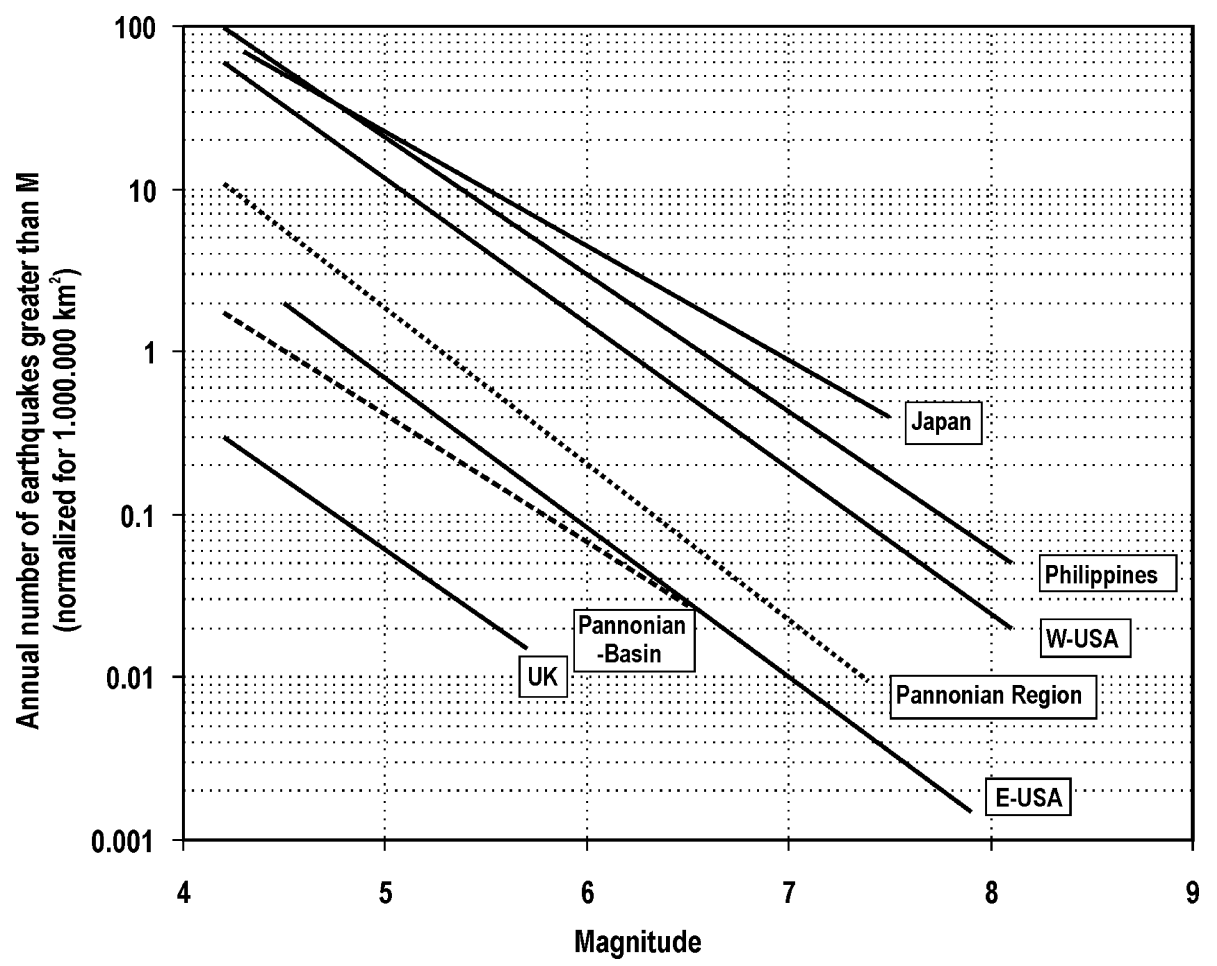

Fig. 1. Seismic activity rate of the Pannonian Region compared to other seismic regions of the world. To be comparable, magnitude recurrence curves have been normalized to a uniform area of $10^{6} \mathrm{~km}^{2}$. Sources - UK: Ove Arup \& Partners (1992); eastern USA: Atkinson (1989); Pannonian Region and Pannonian Basin: present study; western USA: Atkinson (1989); Greece: Tsapanos (1988); Philippines: Ove Arup \& Partners (1990); Japan: Tsapanos (1988).

\section{From early earthquake lists to a comprehensive earthquake data base}

Although very strong $(M>7)$ or catastrophic earthquakes are rare in the Pannonian Region, there is a long history of earthquakes which have caused substantial damage. The first earthquake record from the area dates back to $456 \mathrm{AD}$ when a quake hit Savaria, a town of the Roman Empire (now Szombathely, Hungary) and severely affected large areas (Pleidell, 1934).

Systematic earthquake data collection in the region started in the nineteenth century when the great part of the studied area administratively belonged to Hungary and Austria. A detailed seismological report written by Kitaibel and Tomtsányi (1814) on the great Mór earthquake of 14 January 1810, M 5.4, is the first published paper which contains intensity distribution map with isoseismals. Officially organised collection and evaluation of earthquake data started in 1881. The first seismograph stations were established in 1901, and regular observations started the next year. By the end of 1914, ten seismological observatories had been set up in Hungary at the following locations: Budapest, Fiume (Rijeka), Kalocsa, Kecskemét, Kolozsvár (Cluj-Napoca), Ógyalla (Hurbanovo), Szeged, Temesvár (Timisoara), Ungvár (Uzhgorod), Zágráb (Zagreb). The First World War stopped this progress which had gotten off to a good start. The most important regional catalogue of his- torical earthquakes was published by Réthly (1952) listing approximately 800 well-documented events with references.

The first modern computer-based earthquake catalogue with some 5000 entries was compiled by Zsíros et al. (1988) with the aim of providing a complete revision of the previous lists, a re-evaluation of historical documents and a recalculation of hypocentral data, intensity and magnitude. This work led to a comprehensive catalogue of earthquakes (Zsíros, 2000a) that has been compiled for the Pannonian Region bounded by $44.0-50.0 \mathrm{~N}$ latitude and 13.0-28.0 E longitude using various input sources and integrating several local catalogues. More than one and half millennium of historical and instrumental earthquake data, from 456 AD to 1998, give a reasonable quantitative value, indicating moderately active seismicity of the area. The list consists of more than 20000 events drawn from over 1400 different scientific and scholarly sources, local catalogues, annual bulletins and individual event reports. By its nature, an earthquake catalogue can be neither complete nor without errors, especially if it goes back to historic (pre-instrumental) times. Particularly for periods prior to the $1800 \mathrm{~s}$, reporting of earthquakes is not homogeneous in space or time. Because publications mainly list those earthquakes that have caused death or damage, the number of reports is dependent on the written history available for a particular region, as well as on the rate of development of population centers and related structures. Therefore, it is misleading to use the number of earthquakes in an 


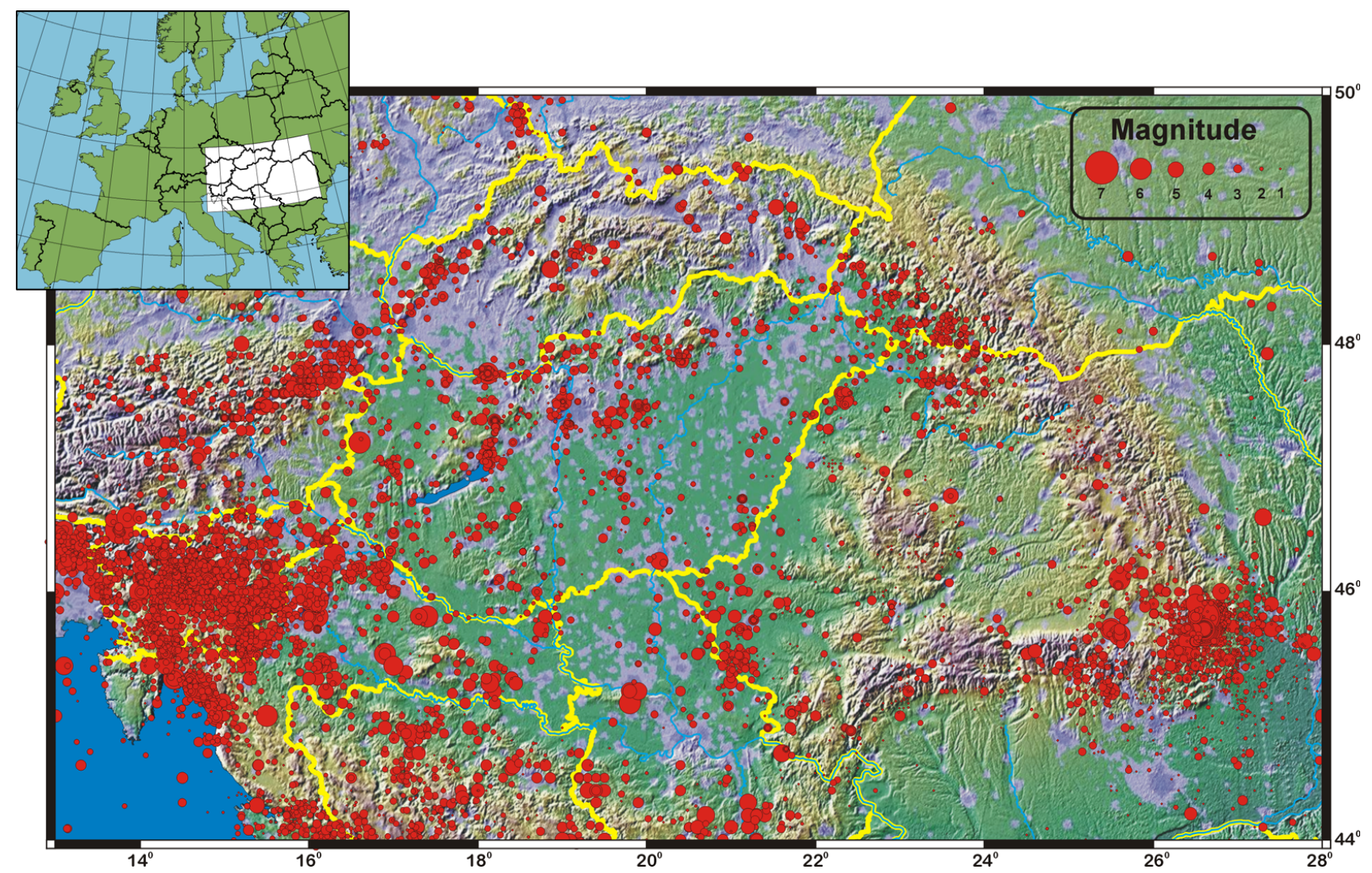

Fig. 2. Distribution of earthquake epicenters in the Pannonian Region (44.0-50.0 N; 13.0-28.0 E). The earthquake database of the region contains more than 20000 historical and instrumentally recorded events from 456 AD until 1998. Events are excluded from the map if the epicenter accuracy is less than $50 \mathrm{~km}$. Size of circles are proportional to the calculated magnitudes.

incomplete catalogue to suggest statistically that there has been an increase in seismic activity for any time period. The present regional catalogue is considered to be complete for earthquakes larger than M 4.7 since 1800.

The catalogue shows significantly more earthquakes in the Carpathian and Dinaric tectonic belt than within the Pannonian Basin itself where the spatial distribution of epicentres is rather diffuse. Based on all events, the seismic activity can be characterised as moderate. Figure 1 shows the activity rate of the Pannonian Region and the Pannonian Basin compared to those of a few other seismic regions of the world.

The first focal mechanism solution for the study area was published by Csomor (1966) for the 1956 Dunaharaszti earthquake. Mónus et al. (1988) presented fault plane solutions for six larger earthquakes in the Pannonian Basin. Tóth et al. (1989) published a well constrained solution for the Berhida (Hungary) earthquake of 1985 based on 88 observations. Gangl (1975) studied five focal solutions from the Vienna Basin. For larger Vrancea earthquakes a number of focal mechanism solutions have been published by different authors (e.g. Fara, 1964; Ritsema, 1974; Oncescu, 1987). Gerner (1995) catalogued earthquake focal mechanism solutions for the whole Pannonian Region, partly collected from literature and partly based on new calculations. In the framework of the international World Stress Map Project (Müller et al., 1997), different types of stress information, together with focal mechanism solutions, have been stored in a standardised manner. Even for smaller magnitude local earthquakes, regular focal mechanism computation has been started and published in annual bulletins (Tóth et al., 1999) since 1995. Until the end of 1998, altogether 190 carefully revised solutions are available for different earthquakes in the focal mechanisms database for the studied area.

From P-wave displacement spectra of high-quality digital seismograms of 12 recent (1995-1997) local earthquakes, Badawy et al. (2001) estimated dynamic source parameters such as seismic moment, stress drop, fault length and relative displacement.

\section{Energy release}

The Pannonian Region is situated in the territory between the Mediterranean area, which is seismically one of the most active regions in the world, and the East European Platform which can be treated as nearly aseismic. The first impression that the earthquake epicenter distribution map (Fig. 2) of the entire catalogue suggests is that there are significantly more earthquakes in the Carpathian and Dinaric tectonic belt than within the Pannonian Basin. Within the Pannonian Basin 


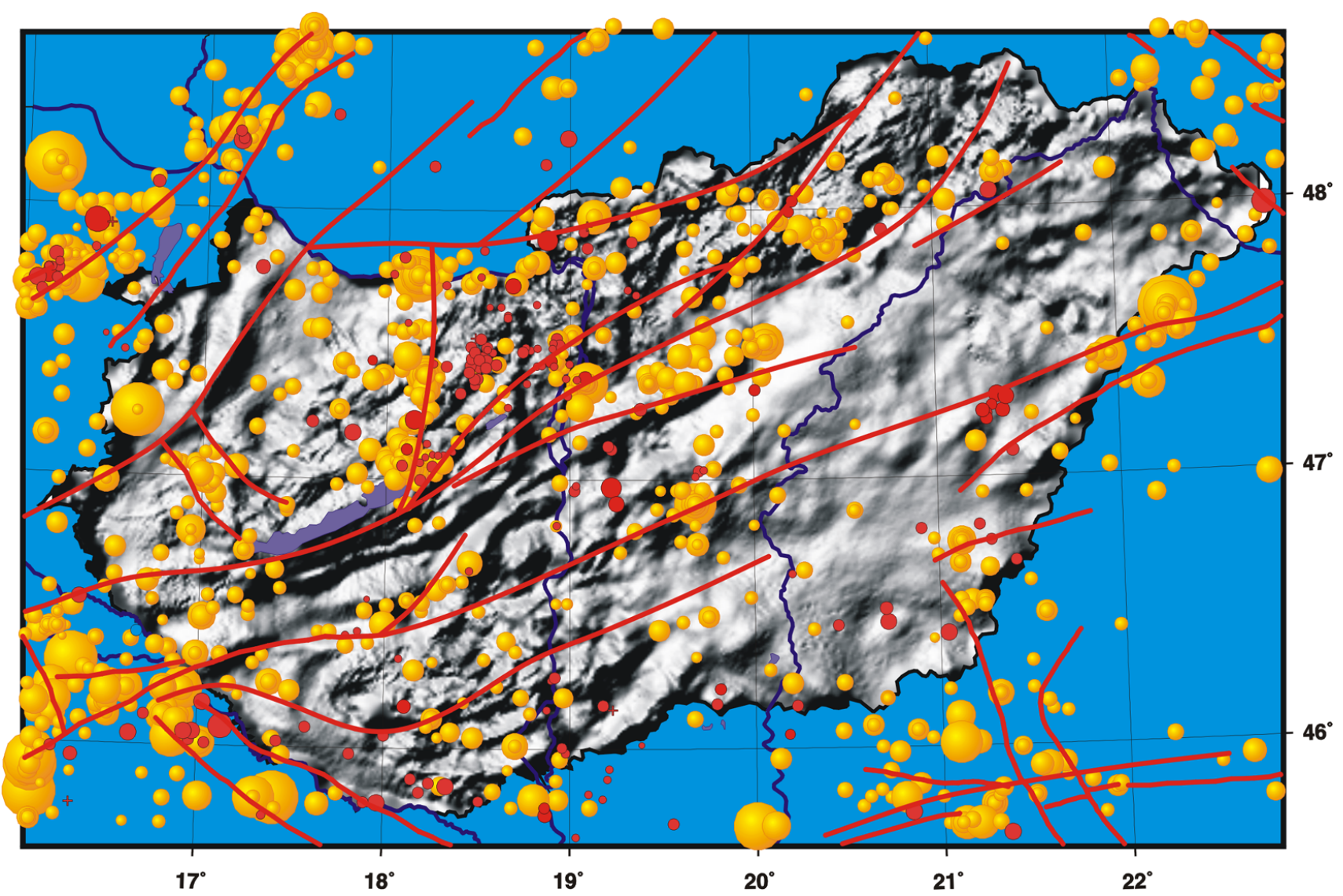

Fig. 3. Historical (456 AD - 1994) and recent (1995-1998) seismicity in and around Hungary (45.5-49.0 N; 16.0-23.0 E) plotted on Bouguer anomaly map. Yellow bubbles show historical events mostly based on macroseismic effects while solid red circles indicate latest epicentral locations measured since high sensitivity digital networks came into operation. Heavy lines show tectonic lineaments as defined by F. Horváth and G. Bada, (personal communication).

there also appears to be significant differences in seismicity among different geographical domains.

Along the western edge of the Pannonian Basin and in the Eastern Alps and Dinarides some well-defined zones of seismic activity can be recognized. Within the Dinaric area, seismic lineaments can be recognized running parallel with the Adriatic coast. These are connected by the very active NESW trending Medvednica zone near Zagreb. A linear seismic source zone in the Eastern Alps, the Mur-Mürz-Zilina line, strikes northeast into the southern Vienna Basin and extends as far as the Little Carpathians.

The seismicity of the Vrancea region in the Southeast Carpathians is characterized by an amazingly narrow epicentral region (Oncescu, 1984). The epicentral area is confined to about $20 \times 60 \mathrm{~km}$, where strong earthquakes $(M>6)$ occur quite frequently.

Seismicity in the Pannonian Basin is more moderate compared to the peripherals and, at first glance, the distribution of earthquake epicenters shows a rather scattered pattern. It is particularly difficult to decide whether the epicenters occur at isolated places or along elongated zones. Csomor and Kiss (1959) have noted that at several individual locations earthquakes occur repeatedly. For example, near Eger (47.9 N;
20.4 E) at least sixteen earthquakes with more than fifty significant aftershocks occurred over a time interval of some 70 years. Komárom and Mór area (47.4-47.8 N; 18.2 E), Jászberény (47.5 N; 20.0 E), Kecskemét (46.9 N; 19.7 E) and Dunaharaszti $(47.4 ; 19.0 \mathrm{E})$ also produced significant activity over a certain, but limited period of time. Moderate seismicity does not necessarily mean moderate size of earthquakes: reports of major earthquakes often refer to heavy building damage, liquefaction (e.g. 1763 Komárom earthquake, M 6.2; 1911 Kecskemét earthquake, M 5.6) and sometimes the possibility of fault rupture (e.g. 1834 Érmellék earthquake, M 6.2). These observations indicate that magnitude 6.0-6.5 earthquakes are possible but not frequent in the Pannonian Basin. Bisztricsány (1978) has illustrated the difficulty in constructing any meaningful geographical pattern of epicentral distribution when the statistical significance of the data is so low. Using only historical and early instrumental data, it really has been very challenging to find strong correlation between known tectonic structures and earthquakes. The recent high quality earthquake observations and locations may change this situation (Tóth et al., 1996, 1997, 1998a, 1999). Preliminary comparison of historical seismicity with recent events shows that the recent earthquakes, in 


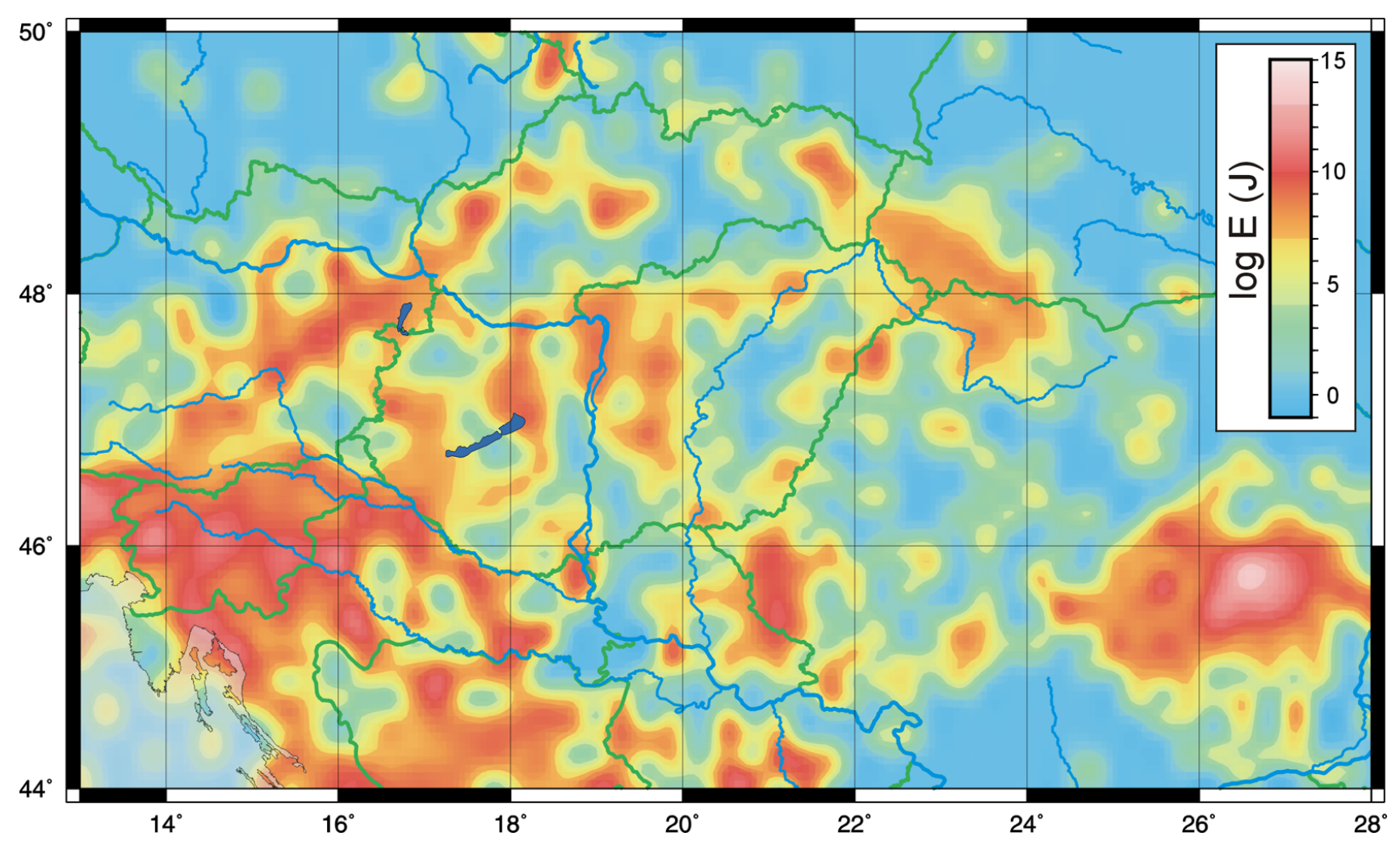

Fig. 4. Spatial distribution of the total seismic energy release in the Pannonian Region. Most dynamic deformation has been taking place in the Dinarides and the Vrancea zone; but rather intense deformation has been taking place in the Pannonian Basin as well.

general, lie near to clusters of historical activity. Only a few events are exceptions, in that they appear to be unassociated with historical activity. However, clusters of stronger present day activity have been detected in the north-eastern part of the Transdanubian Mountain Range, close to the NE coast of lake Balaton and at the bend of the Danube above Budapest (Fig. 3).

The spatial distribution of the total seismic energy release shows (Fig. 4) that the most forceful deformation has been taking place in the Dinarides and the Vrancea zone. However, the deformation occurring in the Pannonian Basin has been considerably more intense than in the rest of the surrounding orogenic belts. The same conclusion was drawn earlier by Gerner et al. (1999). Repeated computation based on our comprehensive data set has confirmed this, and further highlights ongoing tectonic activity in the Pannonian Basin.

\section{Focal depth}

Less than $20 \%$ of the earthquakes - some 3700 - in the catalogue have depth information. Many focal depth values were estimated from macroseismic data (Zsíros, 1989, 1996), and, whilst being the best information currently available, have considerable uncertainty associated with them. It should also be noted that the focal depth determinations from instrumental data are also rather uncertain. The situation has improved since high sensitivity digital networks came into operation, and typical error associated with depth determination has been reduced to about 2-4 km (Tóth et al., 1998b).

Distribution of focal depths suggests three depth provinces where more than $80 \%$ of all events have taken place (Fig. 5). Shallow depth within the top $20 \mathrm{~km}$ of the earth's crust is almost exclusive in the whole region except the Vrancea zone in the Eastern Carpathians. In the Pannonian Basin area, the majority of events occur primarily between 6 and $15 \mathrm{~km}$ below ground level, with many occurring between 6 and $9 \mathrm{~km}$.

The earthquakes in the Vrancea region are characterized by intermediate depth seismicity. Strong earthquakes occur either in the $70-110 \mathrm{~km}$ or $125-160 \mathrm{~km}$ depth domains within an almost vertical column. Deeper and shallower events have been recorded, but only with small magnitudes. Levels of low seismicity lie adjacent to the depth interval of the strong events between 40 and $70 \mathrm{~km}$ and beneath $160 \mathrm{~km}$.

\section{Magnitude}

Instrumental seismology is a young science. The first calibrated instruments to measure seismic waves travelling through the earth and allowing direct measure of earthquake magnitude did not appear until the late 1800s. But, because of the insensitivity of these early instruments they were able to record only large magnitude events.

Richter developed the first magnitude scale for local earthquakes $\left(\mathrm{M}_{\mathrm{L}}\right)$ in 1935 using the logarithm of the amplitude 


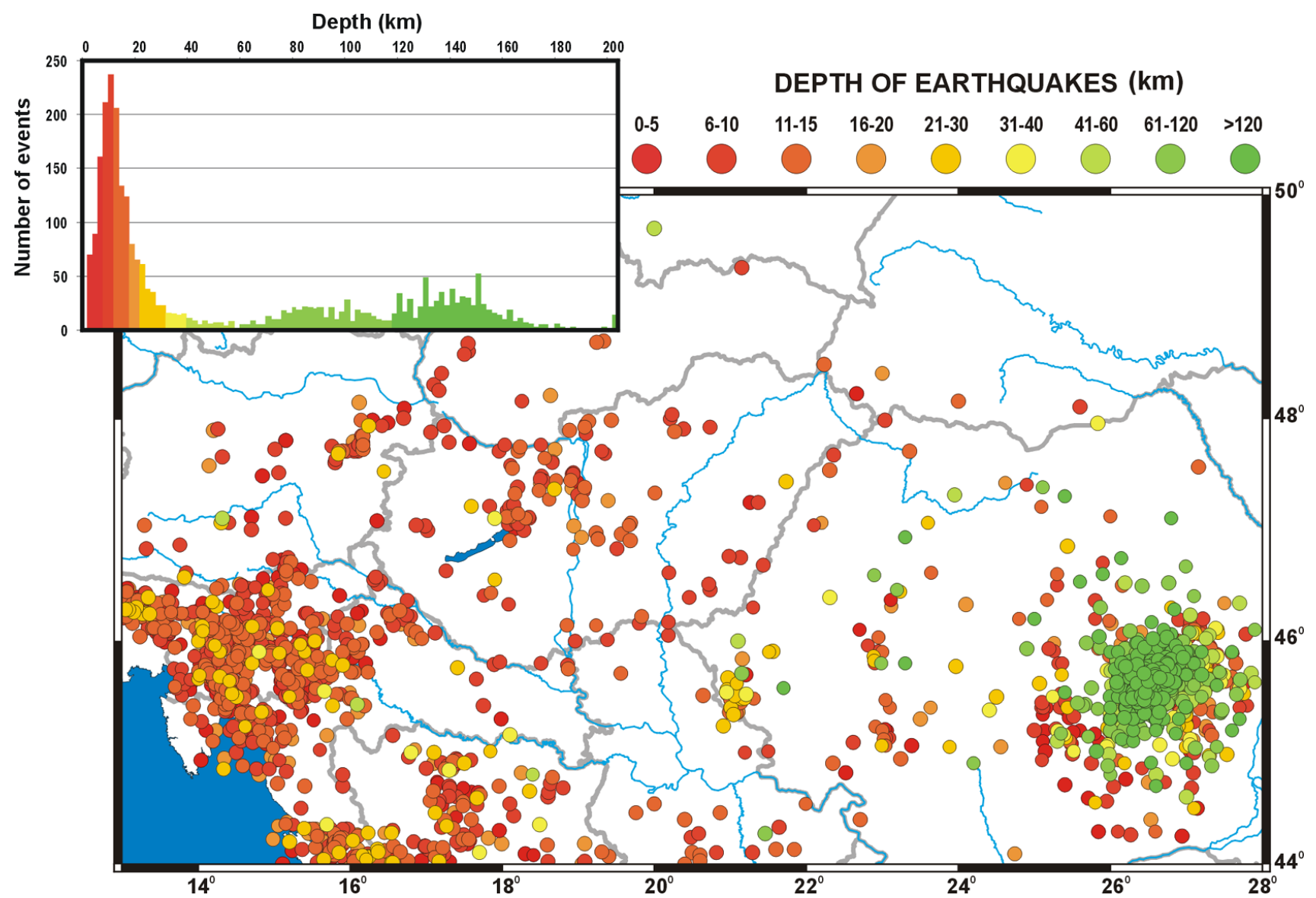

Fig. 5. Hypocenter depth distribution of earthquakes in the Pannonian Region and its surroundings (44.0-50.0 N; 13.0-28.0 E). More than $80 \%$ of all earthquakes occur in three different depth provinces. Shallow depth $(6-15 \mathrm{~km})$ in the upper crust is almost exclusive in the whole region except the Vrancea zone in the Eastern Carpathians, where intermediate depth seismicity is definitive; strong earthquakes occur either in the $70-110 \mathrm{~km}$ or $125-160 \mathrm{~km}$ depth domains.

of waves recorded by seismographs. Owing to the narrow dynamic range of early seismographs, it was often impossible to measure the maximum amplitude of strong seismic movements, and the magnitude determination by duration was a useful and simple way of overcoming this problem. Bisztricsány (1958) proposed the use of the duration of the surface-wave train for the determination of magnitude and obtained the following formulae for Wiechert seismographs at the Budapest station, for shallow and deeper shocks respectively:

$M_{D}=\left\{\begin{array}{l}2.12 \log (F-e L)+0.0065 \Delta+2.66 \\ 1.58 \log (F-e L)+0.0020+0.0007 h+4.02\end{array}\right\}$

where $\mathrm{F}$ and $\mathrm{eL}$ are the end and commencement times in minutes of the recorded surface waves, $\Delta$ is the epicentral distance in degrees and $\mathrm{M}_{\mathrm{D}}$ is the duration magnitude. The method has been adopted at many seismological stations (Willmore, 1979).

In order to estimate the magnitudes for historical earthquakes relationships have been developed by Zsíros (2000b) between "macroseismic" magnitude $(\mathrm{M})$ and epicentral intensity $\left(\mathrm{I}_{0}\right)$.
For the whole Pannonian Region (with the exception of the Vrancea area):

$$
\begin{gathered}
M=0.68( \pm 0.02) I_{0}+0.96( \pm 0.07) \log h-0.91( \pm 0.10) \\
\left\{n=514, I_{0}=I I I-X, M=0.6-6.2, h=1-65\right\}
\end{gathered}
$$

For the Vrancea section:

$$
\begin{array}{r}
M=0.52( \pm 0.02) I_{0}+0.55( \pm 0.11) \log h-1.18( \pm 0.20) \\
\left\{n=514, I_{0}=I I-I X, M=2.4-7.3, h=1-200\right\}
\end{array}
$$

where $\mathrm{M}$ is magnitude, $\mathrm{I}_{0}$ epicentral intensity, and $\mathrm{h}$ is focal depth in $\mathrm{km}$. Number of observations (n), intensity, magnitude and depth intervals are listed in brackets.

Statistical relations have been developed between different magnitudes

$$
\begin{aligned}
& M_{S}=1.03( \pm 0.02) M-0.20( \pm 0.10) \\
& \quad\left\{n=186, M_{S}=2.0-7.0, M=2.0-6.8\right\} \\
& M_{S}=0.97( \pm 0.05) M_{B}+0.04( \pm 0.24) \\
& \quad\left\{n=127, M_{S}=2.5-7.0, M_{B}=2.1-6.4\right\}
\end{aligned}
$$




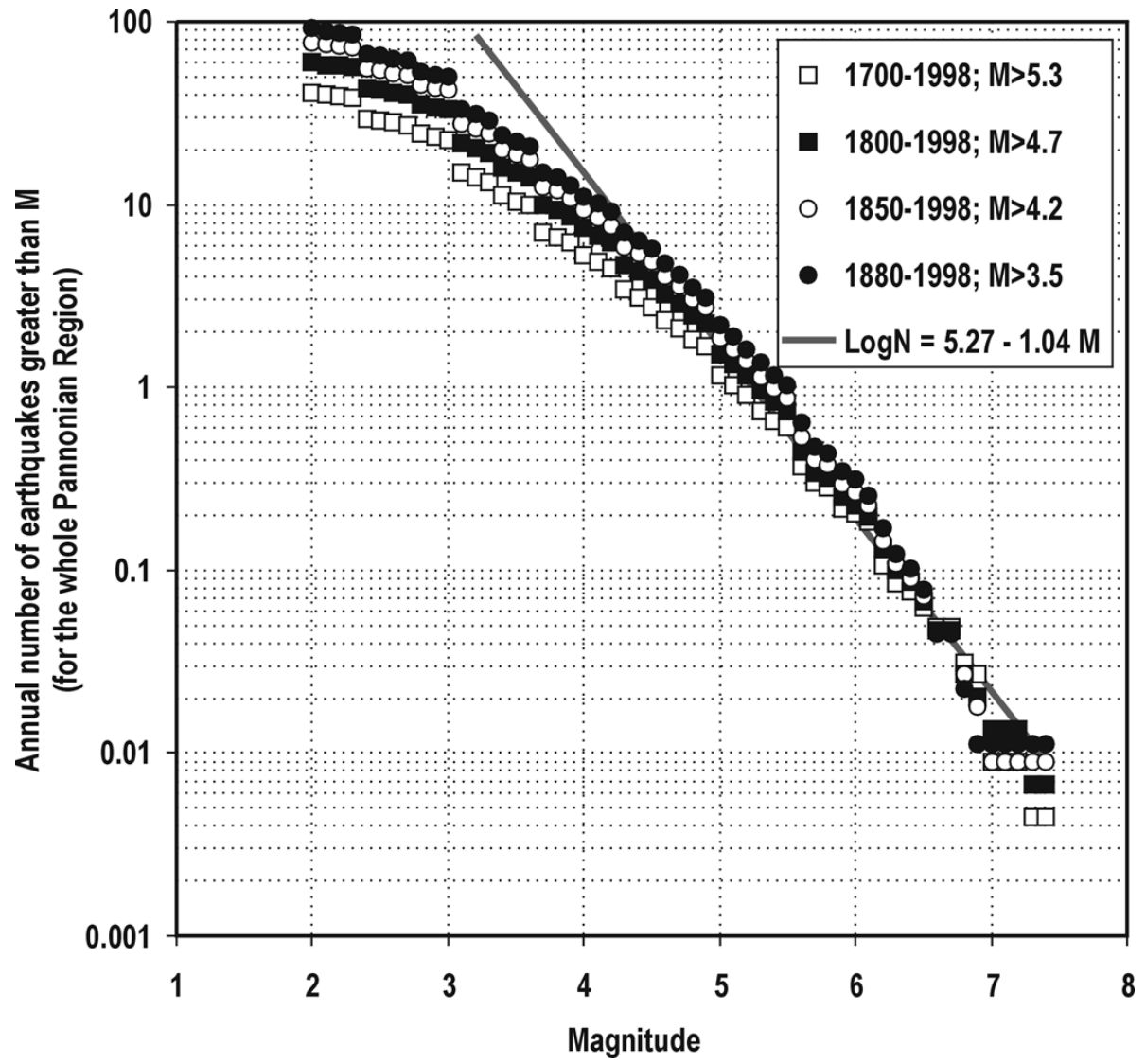

Fig. 6. Magnitude recurrence relationship for the whole earthquake data set (44.0-50.0 N; 13.0-28.0 E) in the conventional form proposed by Gutenberg and Richter (1949). The annual number (expressed as a log to the base 10) of earthquakes greater than magnitude $\mathrm{M}$ is plotted as a function of that magnitude.

$$
\begin{aligned}
& M_{S}=0.86( \pm 0.06) M_{L}+0.57( \pm 0.27) \\
& \left\{n=97, M_{S}=2.0-7.0, M_{L}=2.0-6.6\right\} \\
& M_{S}=1.21( \pm 0.11) M_{D} 1.23( \pm 0.52) \\
& \quad\left\{n=27, M_{S}=2.3-6.9, M_{D}=2.8-6.5\right\} \\
& M_{B}=0.59( \pm 0.05) M_{L}+1.75( \pm 0.22) \\
& \quad\left\{n=259, M_{B}=2.6-6.4, M_{L}=2.1-6.6\right\} \\
& M_{B}=0.90( \pm 0.08) M_{D}+0.20( \pm 0.32) \\
& \quad\left\{n=160, M_{B}=2.6-6.3, M_{D}=3.2-6.5\right\} \\
& M_{L}=1.14( \pm 0.02) M_{D} 0.69( \pm 0.06) \\
& \left\{n=894, M_{L}=0.8-5.5, M_{D}=1.4-5.6\right\}
\end{aligned}
$$

where $\mathrm{M}, \mathrm{M}_{\mathrm{S}}, \mathrm{M}_{\mathrm{B}}, \mathrm{M}_{\mathrm{L}}$, and $\mathrm{M}_{\mathrm{D}}$ are "macroseismic" magnitude, surface wave magnitude, body wave magnitude, local magnitude and duration magnitude, respectively. Number of observations (n) and magnitude intervals are listed in brackets.

Instead of using a single intensity value $\mathrm{I}_{0}$ for magnitude estimation, Ambraseys and Melville (1982) proposed to plot areas within isoseismal IV (A $\mathrm{A}_{\mathrm{IV}}$ ) against instrumental surface wave magnitudes (c). For those Pannonian Basin earth- quakes where both of the above parameters exist, Ove Arup $\&$ Partners (1995) performed a linear regression analysis and concluded that:

$M_{S}=0.97 \log A_{I V}+0.90(\sigma=0.29)$

A simple linear regression between measured surface wave magnitudes $\left(\mathrm{M}_{\mathrm{S}}\right)$ and epicentral intensity $\left(\mathrm{I}_{0}\right)$ for the whole catalogue events, where both $\mathrm{M}_{\mathrm{S}}$ and $\mathrm{I}_{0}$ exist, gives:

$M_{S}=0.74 I_{0}-0.28(\sigma=0.30)$

The estimated macroseismic magnitude (M) and surface wave magnitude $\left(\mathrm{M}_{\mathrm{S}}\right)$ values, calculated either directly from $\mathrm{I}_{0}$ or though $\mathrm{A}_{\mathrm{IV}}$, are generally quite similar, but tend to deviate somewhat at higher values.

To estimate the completeness of the catalogue in different time intervals, magnitude regression has been carried out for all reported events and is displayed in Fig. 6. The catalogue is considered to be complete for earthquakes larger than M 6.4 since 1500, for earthquakes larger than M 5.8 since 1600 , for earthquakes larger than M 4.7 since 1800 and for earthquakes larger than M 4.2 since 1850. For magnitudes greater than 3.5 the catalogue appears to be well de- 


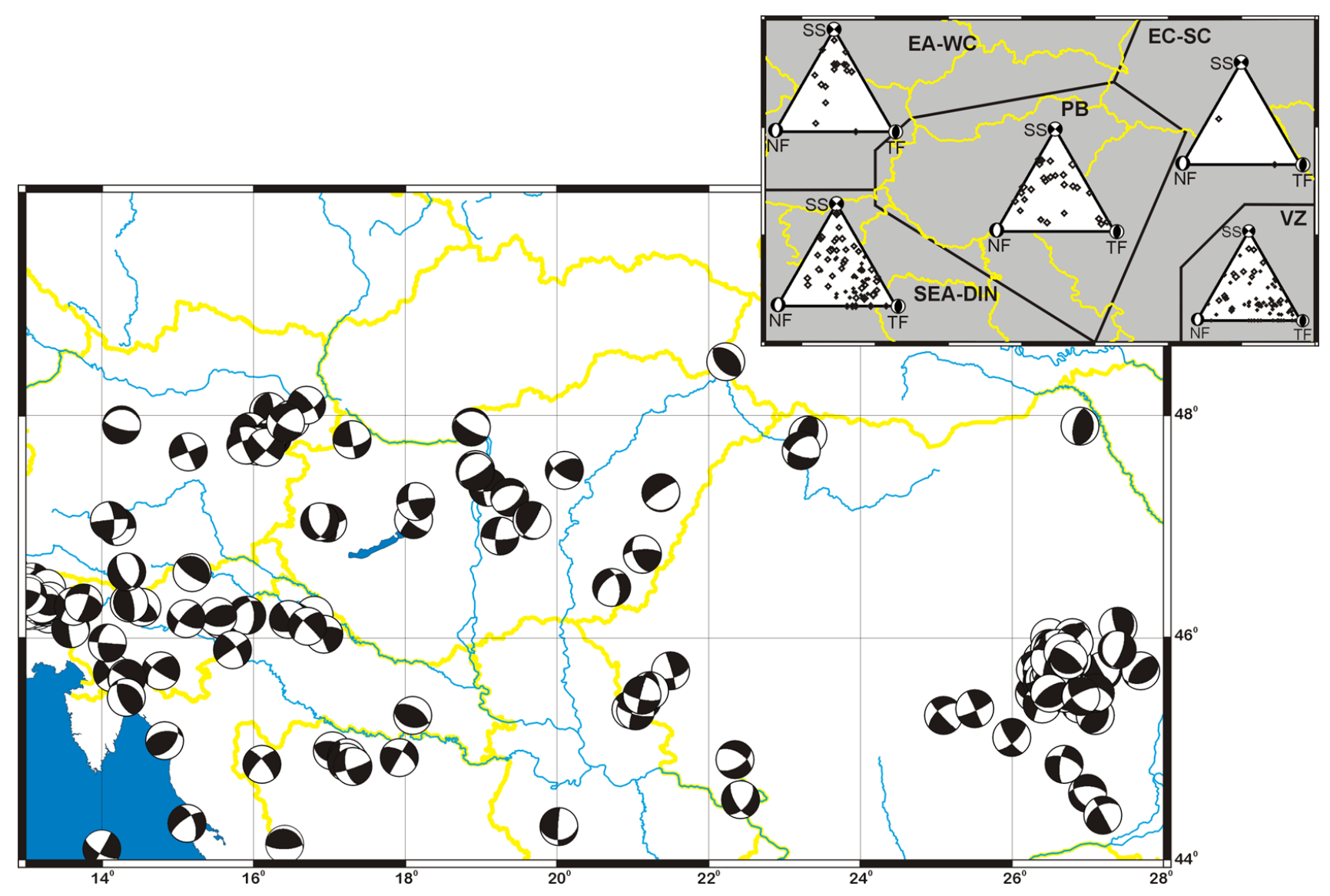

Fig. 7. Focal mechanism solutions for the Pannonian Region. Lower hemisphere stereographic projection is displayed with the compressional quadrants darkened for each mechanism. Summary of solution types such as strike-slip (SS), normal (NF) or thrust fault (TF) are shown in triangle diagrams for each tectonic domain. PB: Pannonian Basin; VZ: Vrancea zone; SEA-DIN: Southeastern Alps and Dinarides; EA-WC: Eastern Alps and Western Carpathians; EC-SC: Eastern Carpathians and Southern Carpathians.

fined since 1880 . The conventional logarithmic relation between the annual number of earthquakes $\mathrm{N}$ and the magnitude M proposed by Gutenberg and Richter (1949) results in:

$\log N=5.27( \pm 0.11)-1.04( \pm 0.02) M$

\{for $M=3.5-7.3$ \}

Based on the magnitude recurrence parameters, altogether the Pannonian Region can be characterized as a seismically reasonably active area with significant variation of seismicity among different tectonic domains. The seismicity rate of the Vrancea region in the Southeast Carpathians is rather high, where strong $(M>6)$ earthquakes occur quite frequently, with typical ground displacements of $30 \mathrm{~cm}$ and peak accelerations on the order of $0.3 \mathrm{~g}$. Within the last two decades three events were detected with magnitudes larger than 6.5 , while magnitude 5.0 earthquakes occur on an almost yearly basis.

In the seismically less active Pannonian Basin area, according to observations since 1880 , the return period of magnitude 6 earthquake is about 20 years, while magnitude 5 events occurs every 3.6 years on average. Based on recordings for the last 4 years, the average annual number of magnitude 3 earthquakes is 2.3 , whilst of magnitude 2 events it is 8.6 (Tóth et al., 1998b).

\section{Focal mechanisms}

Describing the type of fault, associated movement and main stress directions for a given earthquake focal mechanism solutions provides valuable information for understanding the current stress regime and construction of tectonic models of an area. The double-couple origin of earthquake motions divides the area around the earthquake focus into quadrants revealing different directions of motion. Two planes separate the quadrants, the real fault plane and an indistinguishable auxiliary plane. The object of finding an earthquake focal mechanism is to describe the orientations of these planes. Although there have been attempts to derive focal mechanism information of major historical earthquakes, a reliable fault plane solution inevitably requires good quality records at several seismograph stations with azimuthally good coverage.

Until early 1990s only limited good quality earthquake data were available to yield reliable focal mechanism solutions in the studied area, due to the relatively low frequency of larger earthquakes, on one hand, and to the rather poor station coverage, on the other. In the Pannonian Basin the situation was even worse - only a few earthquakes were strong 


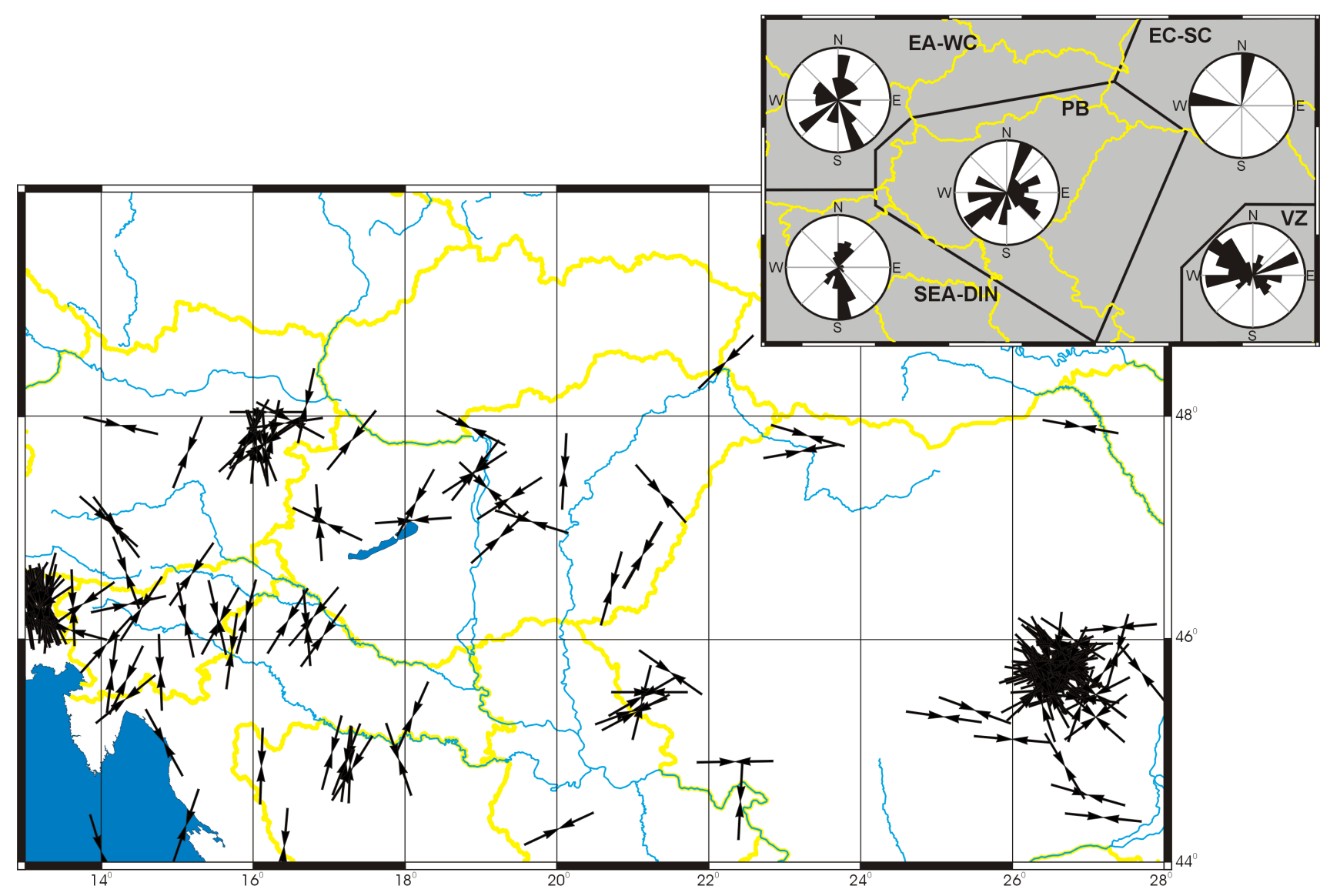

Fig. 8. Maximum horizontal stress directions $\left(\mathrm{S}_{\mathrm{HMAX}}\right)$ derived from earthquake focal mechanism solutions in the Pannonian Region. Rose diagrams show distribution of directions weighted by a quality factor in each tectonic domain. The applied weighting factors are $1,1,0.8$, 0.7 and 0.3 for classes A, B, C, D and E, respectively. PB: Pannonian Basin; VZ: Vrancea zone; SEA-DIN: Southeastern Alps and Dinarides; EA-WC: Eastern Alps and Western Carpathians; EC-SC: Eastern Carpathians and Southern Carpathians.

enough to product focal mechanism solutions. During the last decade, with the installation of sensitive local seismic networks in various countries (e.g. Tóth et al., 1998b), the situation has changed substantially. Nowadays, magnitude 2-3 earthquakes are good candidates, and magnitude 4 events usually result reliable focal mechanism solutions.

In the Pannonian Basin area Csomor (1966) published the first focal mechanism solution for the 1956 Dunaharaszti earthquake. Using P-wave polarity readings from 10 inadequately distributed stations with $282^{\circ}$ azimuthal gap he concluded strike-slip mechanism with nearly vertical nodal planes striking N-S and E-W. Repeated computation based on 26 more soundly distributed arrivals by Mónus et al. (1988) resulted basically in the same nodal planes, but a NWSE principal stress axis instead of the NE-SW given earlier. Tóth et al. (1989) published a well constrained solution for the Berhida (Hungary) earthquake of $1985, \mathrm{~m}_{\mathrm{B}} 4.7$, based on 88 observations and concluded nearly pure strike-slip character with E-W principal stress axis. Gangl (1975) studied five focal solutions from the Vienna Basin. For larger Vrancea earthquakes a number of focal mechanism solutions have been published by different authors (e.g. Fara, 1964;
Ritsema, 1974; Oncescu, 1987).

Gerner (1995) catalogued earthquake focal mechanism solutions for the Pannonian Region, partly collected from the literature and partly based on new calculations. In the framework of the international World Stress Map Project (Müller, 1997), different types of stress information, together with focal mechanism solutions, have been stored in a standardised way. Even for smaller magnitude local earthquakes, regular focal mechanism computation has been started and published in annual bulletins (Tóth et al., 1999) since 1995.

The data set of focal mechanisms used in the present study consists of those collected and catalogued from literature by Gerner (1995), new solutions for events from 1980 to 1993 by Gerner et al. (1999) and latest solutions for mainly Pannonian Basin events from 1995 to 1998 by Tóth et al. (1996, 1997, 1998, 1999).

Until the end of 1998, altogether 190 different carefully revised and qualified solutions are available in our focal mechanisms database for the studied area bounded by $44.0-50.0 \mathrm{~N}$ latitudes and 13.0-28.0 E longitudes. The parameters of focal mechanisms are given by orientation of nodal planes and main axes (angles of strike, dip and rake) followed the con- 
vention by Aki and Richards (1980). Using the Zoback and Zoback (1991) definition for quality designation (A, B, C, D or E, where A is better quality than E) 1, 4, 26, 24 and $45 \%$ of the database entries have been ranked to classes A, B, C, $\mathrm{D}$ and $\mathrm{E}$, respectively.

To summarize and display similarity or diversity of focal mechanisms in a tectonic unit triangle diagrams developed by Fröhlich (1992) have been used. This diagram displays the fractional portions of thrust-faulting, strike-slip faulting and normal faulting of each focal mechanism. Based on apriory seismicity and seismotectonic information, five regions (the Southeastern Alps and Dinarides, Eastern Alps and Western Carpathians, Pannonian Basin, Vrancea zone and Eastern and Southern Carpathians) have been selected in the studied area to characterize faulting mechanisms (Fig. 7).

Largest horizontal stress directions $\mathrm{S}_{\mathrm{HMAX}}$ have been calculated using P, B and T axes of fault plane solutions (Fig. 8). Azimuth of $\mathrm{P}$ axes have been taken as the largest horizontal stress directions, if the plunge of $\mathrm{P}$ is less than $35^{\circ}$ from horizontal. Otherwise azimuth of $\mathrm{T}+90^{\circ}$ or B is used, depending on the plunge of B and T axes according to Zoback (1992). Directions of largest horizontal stresses are summarized for each of the seven tectonic regions on rose diagrams using a quality dependent weighting factor $(1,1,0.8,0.6$, and 0.2 for classes A, B, C, D and E, respectively).

In the Southern Alps and in the Dinarides, seismicity is rather high, and quite a number of fault plane solutions are available. Strike-slip and thrust faulting is almost exclusive in this region. The maximum horizontal stress direction obviously shows N-S and NNE-SSW compression what can be explained by the collision of the Adriatic micro plate with Europe.

Moderately active seismicity is observed in the Eastern Alps and Western Carpathians. Focal mechanism solutions are available mostly from the Vienna Basin area, presenting exclusively strike-slip character. The NNW-SSE and N-S directions of the largest horizontal stresses are most frequent, but NE-SW direction has also occurred.

In the Pannonian Basin, the picture that can be inferred from the relatively few available focal mechanism solutions is more diffuse, however thrust and strike-slip faulting seem to be dominant. The NNE-SSW and NE-SW directions of maximum horizontal stresses are typical, highlighting significant differences from the Western European tectonic domain where the dominant stress direction is exactly perpendicular to this.

Very few fault plane solutions are available from the area of the Eastern and Southern Carpathians indicating thrust faulting mechanisms and E-W dominant stresses.

Most of the events in the Vrancea area occur in a compressive regime with thrust tectonics at intermediate depth. The fault plane solutions of the large, instrumentally recorded earthquakes show a remarkably similar character. They typically strike SW-NE and dip to the NW. The horizontal stress component characteristically displays NW-SE and, in fewer cases, $\mathrm{E}-\mathrm{W}$ directions.

\section{Dynamic source parameters}

Dynamic source parameters derived from P-wave displacement spectra of 12 earthquakes $\left(\mathrm{M}_{\mathrm{L}}\right.$ range from 2.4 to 5.0) in the Pannonian Basin (Badawy et al., 2001) indicate rather low value of corner frequency ranging between 2.5 and $10 \mathrm{~Hz}$. The seismic moments range from $1.5 \times 10^{20}$ to $1.3 \times 10^{23}$ dyne $\mathrm{cm}$, stress drops from 0.25 to $76.75 \mathrm{bar}$, fault length from 0.42 to $1.7 \mathrm{~km}$ and relative displacement from 0.05 to $15.35 \mathrm{~cm}$. The relatively small values of stress drops can be attributed to the low strength of crustal materials in the Pannonian Basin.

\section{Conclusions}

A comprehensive earthquake catalogue has been developed, listing of more than twenty thousand historical and instrumentally recorded earthquakes throughout the Pannonian Region bounded by $44.0-50.0 \mathrm{~N}$ latitude and $13.0-28.0 \mathrm{E}$ longitude. The catalogue is considered to be complete for earthquakes larger than M 6.4 since 1500, for earthquakes larger than M 5.8 since 1600 , for earthquakes larger than M 4.7 since 1800 , for earthquakes larger than M 4.2 since 1850 and for magnitudes greater than 3.5 since 1880 .

Epicenter distribution map of the catalogue suggests that the most active parts of the area are the Carpathian and Dinaric tectonic belt and the Vrancea region in the Southeast Carpathians. Seismicity in the Pannonian Basin is more moderate compared to the peripherals, and the distribution of earthquake epicenters shows a rather scattered pattern however, at several individual locations earthquakes occur repeatedly.

Distribution of focal depths suggests three depth provinces where most of the events have taken place. Shallow depth within the top $20 \mathrm{~km}$ of the earth's crust is almost exclusive in the whole region except the Vrancea zone in the Eastern Carpathians. In the Pannonian Basin area, the majority of events occur primarily between 6 and $15 \mathrm{~km}$ below ground level. The earthquakes of the Vrancea region are characterized by intermediate depth seismicity. Strong earthquakes occur either in the $70-110 \mathrm{~km}$ or $125-160 \mathrm{~km}$ depth domains.

Inferred from focal mechanism solutions, strike-slip and thrust faulting are almost exclusive in the Southern Alps and in the Dinarides, with the maximum horizontal stress directions being N-S and NNE-SSW. In the Eastern Alps and Western Carpathians focal mechanism solutions exhibit an exclusively strike-slip character; with NNW-SSE and N-S directions of the largest horizontal stresses most frequent. In the Pannonian Basin, thrust and strike-slip faulting seem to be dominant, with NNE-SSW and NE-SW directions of maximum horizontal stresses. The very few fault plane solutions available from the Eastern and Southern Carpathians indicate thrust faulting mechanisms and E-W dominant stresses. Strong earthquakes in the Vrancea area occur in a compressive regime with thrust tectonics. The horizontal stress component demonstrates NW-SE and E-W directions. 
Table 1

List of major $(M \geq 5.5)$ earthquakes in the Pannonian Region (44.0-50.0N; 13.0-28.0E) from 456 A.D. until 1998. References for each events can be found in Zsíros (2000) where 1453 different sources are listed.

\begin{tabular}{|c|c|c|c|c|c|c|c|c|c|c|c|c|c|}
\hline \multirow{2}{*}{ No } & \multicolumn{3}{|c|}{ Date } & \multicolumn{2}{|r|}{ Time } & \multicolumn{3}{|c|}{ Location } & \multirow{2}{*}{$\begin{array}{c}\text { Depth } \\
\text { km }\end{array}$} & \multirow{2}{*}{$\begin{array}{c}\text { Magnitude } \\
\text { M }\end{array}$} & \multirow{2}{*}{\multicolumn{2}{|c|}{$\begin{array}{c}\text { Intensity } \\
\text { EMS }\end{array}$}} & \multirow{2}{*}{ Name } \\
\hline & $\mathbf{y y}$ & $\mathbf{m m}$ & dd & h & $\mathbf{m} \quad \mathbf{s}$ & Lat (N) & Long (E) & $\mathbf{Q}$ & & & & & \\
\hline 1 & 456 & 09 & 07 & & & 47.24 & 16.62 & na & & 6.3 & 9.0 & $>+/-1$ & Savaria \\
\hline 2 & 567 & 00 & 00 & & & 45.60 & 15.30 & $>+/-50 \mathrm{~km}$ & & 6.3 & 9.0 & na & Croatia \\
\hline 3 & 984 & 00 & 00 & & & 47.00 & 19.00 & $>+/-50 \mathrm{~km}$ & & 5.6 & 8.0 & $>+/-1$ & Hungary \\
\hline 4 & 1000 & 01 & 00 & & & 46.06 & 14.51 & $>+/-50 \mathrm{~km}$ & & 5.6 & 8.0 & na & Ljubljana \\
\hline 5 & 1038 & 08 & 15 & & & 47.00 & 19.00 & $>+/-50 \mathrm{~km}$ & & 5.6 & 8.0 & $>+/-1$ & Hungary \\
\hline 6 & 1091 & 00 & 00 & & & 45.70 & 26.60 & $>+/-50 \mathrm{~km}$ & & 5.9 & 7.0 & na & Vrancea \\
\hline 7 & 1092 & 07 & 06 & & & 48.00 & 21.00 & $>+/-50 \mathrm{~km}$ & & 5.6 & 8.0 & $>+/-1$ & Hungary \\
\hline 8 & 1097 & 00 & 00 & & & 45.60 & 15.30 & $>+/-50 \mathrm{~km}$ & & 6.3 & 9.0 & na & Croatia \\
\hline 9 & 1100 & 00 & 00 & & & 47.00 & 18.00 & $>+/-50 \mathrm{~km}$ & & 5.6 & 8.0 & $>+/-1$ & Dunántúl \\
\hline 10 & 1107 & 02 & 12 & 03 & & 45.70 & 26.60 & $>+/-50 \mathrm{~km}$ & & 5.9 & 7.0 & na & Vrancea \\
\hline 11 & 1122 & 10 & 00 & & & 45.70 & 26.60 & $>+/-50 \mathrm{~km}$ & & 5.6 & 6.5 & na & Vrancea \\
\hline 12 & 1126 & 08 & 08 & & & 45.70 & 26.60 & $>+/-50 \mathrm{~km}$ & & 5.9 & 7.0 & na & Vrancea \\
\hline 13 & 1196 & 02 & 13 & 07 & & 45.70 & 26.60 & $>+/-50 \mathrm{~km}$ & & 6.4 & 8.0 & $>+/-1$ & Vrancea \\
\hline 14 & 1201 & 05 & 04 & 14 & & 47.10 & 14.20 & na & & 6.6 & 9.5 & na & Murau \\
\hline 15 & 1230 & 05 & 10 & 07 & & 45.70 & 26.60 & $>+/-50 \mathrm{~km}$ & & 6.7 & 8.5 & $>+/-1$ & Vrancea \\
\hline 16 & 1267 & 05 & 08 & 02 & & 47.51 & 15.45 & $>+/-50 \mathrm{~km}$ & & 5.6 & 8.0 & na & Kindberg \\
\hline 17 & 1279 & 04 & 24 & 19 & & 45.93 & 13.40 & $>+/-50 \mathrm{~km}$ & & 5.6 & 8.0 & na & Friuli \\
\hline 18 & 1287 & 06 & 23 & & & 47.00 & 19.00 & $>+/-50 \mathrm{~km}$ & & 5.6 & 8.0 & $>+/-1$ & Hungary \\
\hline 19 & 1323 & 00 & 00 & & & 45.20 & 14.70 & $>+/-50 \mathrm{~km}$ & & 6.3 & 9.0 & na & Croatia \\
\hline 20 & 1327 & 00 & 00 & & & 45.70 & 26.60 & $>+/-50 \mathrm{~km}$ & & 6.4 & 8.0 & na & Vrancea \\
\hline 21 & 1343 & 06 & 30 & & & 44.00 & 15.00 & $>+/-50 \mathrm{~km}$ & & 6.3 & 9.0 & na & Croatia \\
\hline 22 & 1348 & 01 & 25 & & & 46.50 & 13.45 & $<+/-20 \mathrm{~km}$ & & 6.6 & 9.5 & na & Villach \\
\hline 23 & 1366 & 06 & 03 & & & 50.00 & 13.00 & $>+/-50 \mathrm{~km}$ & & 5.6 & 8.0 & na & Bohemia \\
\hline 24 & 1386 & 00 & 00 & & & 44.20 & 17.70 & $>+/-50 \mathrm{~km}$ & & 6.3 & 9.0 & na & Bosnia \\
\hline 25 & 1389 & 08 & 20 & 11 & & 46.43 & 13.18 & $>+/-50 \mathrm{~km}$ & & 5.6 & 8.0 & na & Moggio Udinese \\
\hline 26 & 1418 & 04 & 07 & & & 44.00 & 15.00 & $>+/-50 \mathrm{~km}$ & & 6.3 & 9.0 & na & Croatia \\
\hline 27 & 1443 & 06 & 05 & & & 48.60 & 18.86 & $<+/-20 \mathrm{~km}$ & & 5.6 & 8.0 & $+/-1$ & Zólyom \\
\hline 28 & 1444 & 08 & 04 & & & 46.26 & 20.15 & na & & 5.6 & 8.0 & $>+/-1$ & Szeged \\
\hline 29 & 1446 & 10 & 10 & & & 45.70 & 26.60 & $>+/-50 \mathrm{~km}$ & & 6.7 & 8.5 & na & Vrancea \\
\hline 30 & 1459 & 05 & 20 & & & 46.30 & 16.30 & na & & 6.3 & 9.0 & na & Croatia \\
\hline 31 & 1471 & 08 & 29 & 11 & & 45.70 & 26.60 & na & & 6.4 & 8.0 & $>+/-1$ & Vrancea \\
\hline 32 & 1473 & 08 & 29 & & & 45.60 & 26.00 & na & & 5.9 & 7.0 & $>+/-1$ & Barcaság \\
\hline 33 & 1502 & 03 & 26 & 13 & & 45.80 & 16.10 & na & & 6.3 & 9.0 & na & Croatia \\
\hline 34 & 1505 & 00 & 00 & & & 45.00 & 15.50 & na & & 6.3 & 9.0 & na & Croatia \\
\hline 35 & 1510 & 00 & 00 & & & 46.10 & 14.50 & na & & 6.3 & 9.0 & na & Croatia \\
\hline 36 & 1511 & 03 & 26 & 14 & & 46.10 & 14.00 & na & 15 & 7.0 & 10.0 & na & Idrija-Cerkno \\
\hline 37 & 1511 & 06 & 26 & 21 & & 46.00 & 14.03 & na & & 5.6 & 8.0 & na & Idrija \\
\hline 38 & 1511 & 08 & 08 & & & 46.00 & 14.00 & na & & 6.3 & 9.0 & na & Idrija-Cerkno \\
\hline 39 & 1516 & 11 & 24 & 12 & & 45.70 & 26.60 & na & & 6.9 & 9.0 & na & Mt. Háromszék \\
\hline 40 & 1523 & 06 & 09 & & & 45.70 & 26.60 & na & & 5.9 & 7.0 & na & Mt. Háromszék \\
\hline 41 & 1543 & 00 & 00 & & & 45.70 & 26.60 & na & & 5.9 & 7.0 & na & Mt. Háromszék \\
\hline 42 & 1545 & 07 & 19 & & & 45.70 & 26.60 & na & & 6.4 & 8.0 & na & Mt. Háromszék \\
\hline 43 & 1556 & 01 & 24 & & & 48.00 & 15.00 & $>+/-50 \mathrm{~km}$ & & 5.6 & 8.0 & $>+/-1$ & Western Hungary \\
\hline 44 & 1561 & 02 & 12 & & & 47.50 & 19.05 & na & & 5.6 & 8.0 & $>+/-1$ & Pest-Buda \\
\hline 45 & 1569 & 08 & 17 & 05 & & 45.70 & 26.60 & na & & 6.4 & 8.0 & na & Mt. Háromszék \\
\hline 46 & 1571 & 04 & 10 & 07 & & 45.60 & 26.00 & na & & 5.9 & 7.0 & $>+/-1$ & Barcaság \\
\hline
\end{tabular}


Table 1 (Cont.)

\begin{tabular}{|c|c|c|c|c|c|c|c|c|c|c|c|c|}
\hline 47 & 157105 & 19 & 17 & & 45.60 & 26.00 & na & & 5.9 & 7.0 & $>+/-1$ & Barcaság \\
\hline 48 & 157408 & 14 & & & 45.40 & 14.10 & na & & 5.6 & 8.0 & na & Croatia \\
\hline 49 & 157804 & 01 & & & 45.70 & 26.60 & na & & 5.9 & 7.0 & na & Mt. Háromszék \\
\hline 50 & 158501 & 01 & & & 47.50 & 16.30 & $>+/-50 \mathrm{~km}$ & & 5.6 & 8.0 & $>+/-1$ & Western Hungary \\
\hline 51 & 159008 & 10 & 20 & & 45.70 & 26.60 & na & & 6.7 & 8.5 & na & Mt. Háromszék \\
\hline 52 & 159009 & 15 & 23 & & 48.28 & 16.11 & $<+/-20 \mathrm{~km}$ & & 6.3 & 9.0 & na & Katzelsdorf \\
\hline 53 & 159009 & 22 & & & 45.60 & 26.00 & na & & 5.9 & 7.0 & $>+/-1$ & Barcaság \\
\hline 54 & 159504 & 21 & 11 & & 45.60 & 26.00 & na & & 6.4 & 8.0 & $>+/-1$ & Barcaság \\
\hline 55 & 159604 & 16 & & & 45.70 & 26.60 & $>+/-50 \mathrm{~km}$ & & 5.6 & 6.5 & na & Vrancea \\
\hline 56 & 159811 & 22 & 02 & & 45.70 & 26.60 & na & & 5.9 & 7.0 & na & Mt. Háromszék \\
\hline 57 & 159908 & 04 & & & 45.70 & 26.60 & na & & 5.9 & 7.0 & na & Mt. Háromszék \\
\hline 58 & 159910 & 01 & 08 & & 47.76 & 18.12 & $>+/-50 \mathrm{~km}$ & & 5.6 & 8.0 & $>+/-1$ & Komárom \\
\hline 59 & 160405 & 03 & 03 & & 45.70 & 26.60 & na & & 6.4 & 8.0 & na & Mt. Háromszék \\
\hline 60 & 160512 & 24 & 15 & & 45.70 & 26.60 & na & & 6.4 & 8.0 & na & Vrancea \\
\hline 61 & 160601 & 13 & 02 & & 45.70 & 26.60 & na & & 6.2 & 7.5 & na & Mt. Háromszék \\
\hline 62 & 161311 & 16 & 11 & & 49.22 & 18.74 & $>+/-50 \mathrm{~km}$ & & 5.6 & 8.0 & $>+/-1$ & Zsolna \\
\hline 63 & 162011 & 08 & 13 & & 45.80 & 26.60 & na & & 6.7 & 8.5 & na & Vrancea \\
\hline 64 & 162012 & 00 & & & 45.70 & 26.60 & na & & 6.2 & 7.5 & na & Vrancea \\
\hline 65 & 162806 & 17 & 18 & & 45.97 & 15.48 & $<+/-20 \mathrm{~km}$ & & 5.6 & 8.0 & na & Krsko-Brestanica \\
\hline 66 & 163702 & 01 & 01 & 30 & 45.70 & 26.60 & na & & 6.2 & 7.5 & na & Vrancea \\
\hline 67 & 164000 & 00 & & & 45.90 & 15.60 & $<+/-20 \mathrm{~km}$ & & 6.3 & 9.0 & na & Brezice \\
\hline 68 & 164506 & 28 & & & 45.60 & 15.40 & na & & 5.6 & 8.0 & na & Croatia \\
\hline 69 & 164800 & 00 & & & 44.98 & 14.90 & na & & 5.6 & 8.0 & na & Croatia \\
\hline 70 & 165004 & 19 & & & 45.70 & 26.60 & $>+/-50 \mathrm{~km}$ & & 5.9 & 7.0 & na & Vrancea \\
\hline 71 & 166002 & 08 & 01 & & 45.70 & 26.60 & na & & 5.6 & 6.5 & na & Vrancea \\
\hline 72 & 166602 & 00 & & & 45.70 & 26.60 & na & & 5.6 & 6.5 & na & Mt. Háromszék \\
\hline 73 & 168108 & 19 & 01 & & 45.70 & 26.60 & na & & 6.4 & 8.0 & $>+/-1$ & Vrancea \\
\hline 74 & 168903 & 10 & & & 45.97 & 14.85 & na & & 5.6 & 8.0 & na & Slovenia \\
\hline 75 & 168905 & 10 & 03 & & 45.97 & 14.85 & $<+/-20 \mathrm{~km}$ & & 5.6 & 8.0 & na & Temenice \\
\hline 76 & 169012 & 04 & 15 & 45 & 46.60 & 13.80 & $<+/-20 \mathrm{~km}$ & & 5.9 & 8.5 & na & Villach \\
\hline 77 & 169703 & 15 & & & 45.63 & 15.46 & na & & 5.6 & 8.0 & na & Croatia \\
\hline 78 & 169902 & 11 & & & 45.65 & 15.32 & $<+/-20 \mathrm{~km}$ & & 5.6 & 8.0 & na & Metlika \\
\hline 79 & 170106 & 12 & 00 & & 45.70 & 26.60 & na & & 6.2 & 7.5 & na & Vrancea \\
\hline 80 & 171110 & 11 & 01 & & 45.70 & 26.60 & na & & 5.9 & 7.0 & na & Mt. Háromszék \\
\hline 81 & $\begin{array}{ll}1721 & 01\end{array}$ & 12 & & & 45.30 & 14.40 & na & & 6.3 & 9.0 & na & Croatia \\
\hline 82 & 173000 & 00 & & & 45.70 & 26.60 & na & & 6.4 & 8.0 & $>+/-1$ & Vrancea \\
\hline 83 & 173806 & 11 & 10 & & 45.70 & 26.60 & na & 109 & 6.7 & 8.5 & na & Vrancea \\
\hline 84 & 173902 & 04 & & & 44.00 & 21.30 & na & & 6.3 & 9.0 & na & Svetozarevo \\
\hline 85 & 173912 & 20 & 15 & 24 & 45.19 & 19.81 & na & & 5.6 & 8.0 & na & Ledinci \\
\hline 86 & 174004 & 05 & 20 & & 45.70 & 26.60 & na & & 5.6 & 6.5 & na & Mt. Háromszék \\
\hline 87 & 174612 & 07 & 01 & & 45.60 & 26.00 & na & & 5.9 & 7.0 & $>+/-1$ & Barcaság \\
\hline 88 & 175707 & 08 & 03 & & 45.83 & 17.39 & na & & 5.6 & 8.0 & na & Mt. Bilo \\
\hline 89 & 176306 & 28 & 04 & 30 & 47.76 & 18.12 & $<+/-20 \mathrm{~km}$ & & 6.3 & 9.0 & $+/-1$ & Komárom \\
\hline 90 & 176802 & 27 & 01 & 45 & 47.82 & 16.20 & $<+/-10 \mathrm{~km}$ & & 5.6 & 8.0 & na & Bécsújhely \\
\hline 91 & 177801 & 18 & 05 & 45 & 45.70 & 26.60 & na & & 5.9 & 7.0 & $+/-1$ & Háromszék \\
\hline 92 & 177811 & 08 & 19 & 30 & 46.20 & 16.80 & na & & 5.6 & 8.0 & na & Croatia \\
\hline 93 & 178403 & 18 & & & 46.02 & 25.59 & na & & 5.9 & 7.0 & $+/-1$ & Miklósvár \\
\hline 94 & 178602 & 27 & 03 & & 49.70 & 18.50 & na & 38 & 5.7 & 7.5 & na & Silesia \\
\hline 95 & 178612 & 03 & 16 & & 49.67 & 19.86 & na & 42 & 5.7 & 7.5 & na & Poland \\
\hline 96 & 178701 & 18 & & & 45.70 & 26.60 & $>+/-50 \mathrm{~km}$ & & 5.9 & 7.0 & na & Mt. Háromszék \\
\hline 97 & 178810 & 20 & & & 46.38 & 13.02 & na & & 5.9 & 8.5 & na & Tolmezzo \\
\hline 98 & 178811 & 22 & 10 & 30 & 45.20 & 19.90 & na & & 5.6 & 8.0 & $>+/-1$ & Serbia \\
\hline
\end{tabular}


Table 1 (Cont.)

\begin{tabular}{|c|c|c|c|c|c|c|c|c|c|c|c|c|c|c|}
\hline 99 & 179001 & 26 & 07 & 30 & & 46.42 & 13.02 & $<+/-20 \mathrm{~km}$ & & 6.3 & & 9.0 & na & Tolmezzo \\
\hline 100 & 179000 & 00 & & & & 46.40 & 13.00 & $<+/-20 \mathrm{~km}$ & & 5.9 & & 8.5 & na & Tolmezzo \\
\hline 101 & 179004 & 06 & 20 & & & 45.70 & 26.60 & na & 74 & 6.4 & & 8.0 & na & Vrancea \\
\hline 102 & 179312 & 08 & 18 & & & 45.70 & 26.60 & na & & 6.4 & & 8.0 & na & Mt. Háromszék \\
\hline 103 & 179402 & 06 & 12 & 18 & & 47.38 & 15.09 & na & & 5.6 & & 8.0 & na & Leoben \\
\hline 104 & 180201 & 03 & 06 & 30 & & 45.40 & 14.30 & na & & 5.6 & & 8.0 & na & Croatia \\
\hline 105 & 180210 & 26 & 11 & 25 & & 45.70 & 26.60 & na & & 7.2 & & 9.5 & na & Mt. Háromszék \\
\hline 106 & 181203 & 05 & 12 & 30 & & 45.70 & 26.60 & na & & 5.9 & & 7.0 & na & Mt. Háromszék \\
\hline 107 & 181302 & 01 & & & & 45.70 & 26.60 & na & & 5.9 & & 7.0 & $>+/-1$ & Mt. Háromszék \\
\hline 108 & 182102 & 09 & 01 & 30 & & 45.70 & 26.60 & na & & 5.6 & & 6.5 & na & Mt. Háromszék \\
\hline 109 & 182111 & 17 & 13 & 45 & & 45.70 & 26.60 & na & & 5.6 & & 6.5 & na & Vrancea \\
\hline 110 & 182911 & 26 & 02 & 40 & & 45.70 & 26.60 & na & & 6.4 & & 8.0 & $+/-1$ & Vrancea \\
\hline 111 & 183410 & 15 & 06 & 30 & & 47.53 & 22.31 & $<+/-10 \mathrm{~km}$ & 13 & 6.3 & & 9.0 & $+/-1$ & Érmellék \\
\hline 112 & 183504 & 21 & 20 & 30 & & 45.70 & 26.60 & na & & 5.9 & & 7.0 & na & Vrancea \\
\hline 113 & 183801 & 23 & 19 & 30 & & 45.70 & 26.60 & na & & 6.9 & & 9.0 & na & Mt. Háromszék \\
\hline 114 & 183802 & 10 & 03 & 55 & & 45.70 & 26.60 & na & & 5.9 & & 7.0 & $>+/-1$ & Mt. Háromszék \\
\hline 115 & 185801 & 15 & 19 & 15 & & 49.22 & 18.74 & $<+/-10 \mathrm{~km}$ & & 5.6 & & 8.0 & $+/-1$ & Zsolna \\
\hline 116 & 186210 & 16 & 01 & 11 & & 45.70 & 26.60 & na & & 5.6 & & 6.5 & na & Mt. Háromszék \\
\hline 117 & 186811 & 13 & 07 & 45 & & 45.70 & 26.60 & na & & 6.2 & & 7.5 & na & Mt. Háromszék \\
\hline 118 & 186811 & 27 & 21 & 35 & & 45.70 & 26.60 & na & & 5.9 & & 7.0 & na & Mt. Háromszék \\
\hline 119 & 186901 & 10 & 19 & 30 & & 45.70 & 26.60 & na & & 5.9 & & 7.0 & $>+/-1$ & Vrancea \\
\hline 120 & 187003 & 01 & 19 & 57 & & 45.33 & 14.44 & na & & 5.6 & & 8.0 & na & Fiume \\
\hline 121 & 187201 & 23 & 21 & 10 & & 45.70 & 26.60 & na & & 5.9 & & 7.0 & $>+/-1$ & Mt. Háromszék \\
\hline 122 & 187809 & 23 & 20 & 20 & & 45.00 & 14.90 & na & & 5.6 & & 8.0 & na & Croatia \\
\hline 123 & 188011 & 09 & 06 & 33 & 53 & 45.82 & 15.98 & $<+/-20 \mathrm{~km}$ & 13 & 6.3 & & 9.0 & $+/-1$ & Zágráb \\
\hline 124 & 188012 & 25 & 15 & 30 & & 45.70 & 26.60 & na & & 5.9 & & 7.0 & na & Vrancea \\
\hline 125 & 189304 & 08 & 13 & 46 & & 44.12 & 21.36 & $<+/-20 \mathrm{~km}$ & 15 & 6.3 & & 9.0 & $+/-1$ & Serbia \\
\hline 126 & 189305 & 20 & 20 & 42 & & 44.30 & 21.20 & na & & 5.6 & & 8.0 & na & Serbia \\
\hline 127 & 189308 & 17 & 14 & 35 & & 45.70 & 26.60 & na & 108 & 5.9 & & 7.0 & na & Vrancea \\
\hline 128 & 189309 & 10 & 03 & 40 & & 45.70 & 26.60 & na & & 5.6 & & 6.5 & na & Vrancea \\
\hline 129 & 189403 & 04 & 06 & 35 & & 46.07 & 26.65 & na & & 5.9 & & 7.0 & na & Mt. Háromszék \\
\hline 130 & 189408 & 31 & 12 & 20 & & 45.70 & 26.60 & na & & 5.9 & & 7.0 & na & Mt. Háromszék \\
\hline 131 & 189504 & 14 & 22 & 17 & 30 & 46.11 & 14.50 & $<+/-20 \mathrm{~km}$ & 22 & 6.2 & & 8.5 & na & Ljubljana \\
\hline 132 & 189506 & 21 & 10 & & & 44.10 & 20.10 & na & & 5.6 & & 8.0 & $>+/-1$ & Serbia \\
\hline 133 & 190309 & 13 & 08 & 02 & 41 & 45.12 & 26.54 & na & & 6.1 & + & 6.5 & na & Mt. Háromszék \\
\hline 134 & 190402 & 06 & 02 & 49 & & 45.70 & 26.60 & na & 75 & 5.7 & + & 6.0 & na & Vrancea \\
\hline 135 & 190512 & 17 & 22 & 16 & 33 & 45.82 & 15.98 & $<+/-20 \mathrm{~km}$ & 7 & 5.6 & + & 7.5 & na & Zágráb \\
\hline 136 & 190601 & 02 & 04 & 26 & 36 & 45.92 & 16.10 & $<+/-20 \mathrm{~km}$ & 10 & 6.1 & + & 8.0 & na & Zágráb \\
\hline 137 & 190601 & 09 & 23 & 05 & & 48.59 & 17.46 & $<+/-20 \mathrm{~km}$ & 10 & 5.7 & + & 8.0 & $+/-1$ & Jókő \\
\hline 138 & 190610 & 16 & 23 & 25 & & 46.60 & 27.40 & na & & 5.5 & + & 5.0 & na & Moldavia \\
\hline 139 & 190810 & 06 & 21 & 39 & 48 & 45.50 & 26.50 & na & 78 & 6.8 & + & 8.0 & na & Mt. Háromszék \\
\hline 140 & 190901 & 13 & 00 & 45 & & 45.00 & 13.00 & na & & 5.6 & + & & na & Adriatic \\
\hline 141 & 190910 & 08 & 09 & 59 & 7 & 45.48 & 16.09 & $<+/-20 \mathrm{~km}$ & 12 & 6.0 & + & 8.5 & na & Vratecko \\
\hline 142 & 191107 & 08 & 01 & 02 & & 46.91 & 19.69 & $<+/-20 \mathrm{~km}$ & 12 & 5.6 & + & 8.0 & $+/-1$ & Kecskemét \\
\hline 143 & 191205 & 25 & 18 & 01 & 42 & 45.70 & 27.16 & na & $80+$ & 6.0 & + & 7.0 & na & Moldavia \\
\hline 144 & 191205 & 25 & 20 & 15 & & 45.70 & 27.16 & na & $80+$ & 6.2 & + & 6.0 & na & Moldavia \\
\hline 145 & 191205 & 25 & 21 & 15 & & 46.01 & 27.29 & na & $80+$ & 6.0 & + & 5.0 & na & Moldavia \\
\hline 146 & 191303 & 14 & 03 & 40 & & 45.60 & 27.39 & na & & 5.6 & + & 5.0 & na & Vrancea \\
\hline 147 & 191601 & 26 & 07 & 37 & 54 & 45.44 & 24.54 & na & & 6.4 & + & 9.0 & $+/-1$ & Mt. Fogaras \\
\hline 148 & 191603 & 12 & 03 & 23 & 59 & 45.10 & 14.81 & na & 12 & 5.8 & + & 8.0 & na & Croatia \\
\hline 149 & 191701 & 29 & 08 & 22 & 55 & 45.90 & 15.57 & $<+/-20 \mathrm{~km}$ & 5 & 5.6 & + & 8.0 & na & Brezice \\
\hline 150 & 191707 & 11 & 03 & 23 & 55 & 45.70 & 26.60 & na & & 5.5 & + & 6.0 & na & Mt. Háromszék \\
\hline
\end{tabular}


Table 1 (Cont.)

\begin{tabular}{|c|c|c|c|c|c|c|c|c|c|c|c|c|c|c|}
\hline 151 & 191811 & 06 & 192 & 26 & 8 & 46.17 & 14.37 & $<+/-10 \mathrm{~km}$ & & 5.5 & + & 5.0 & na & Slovenia \\
\hline 152 & 192203 & 24 & 12 & 22 & 14 & 44.40 & 20.40 & $<+/-10 \mathrm{~km}$ & 6 & 6.0 & + & 9.0 & na & Serbia \\
\hline 153 & 192601 & 01 & 18 & 04 & 3 & 45.77 & 14.37 & $<+/-20 \mathrm{~km}$ & 13 & 5.6 & + & 7.5 & na & Cerknica \\
\hline 154 & 192705 & 15 & 02 & 47 & 22 & 44.14 & 20.50 & $<+/-10 \mathrm{~km}$ & 9 & 5.9 & + & 9.0 & na & Rudnik \\
\hline 155 & 192803 & 27 & 02 & 32 & 30 & 46.35 & 13.00 & na & & 6.0 & + & 9.0 & na & Friuli \\
\hline 156 & 192911 & 01 & 06 & 57 & 25 & 45.90 & 26.50 & na & $160+$ & 6.2 & + & 6.5 & na & Háromszék \\
\hline 157 & 193403 & 29 & 20 & 06 & 51 & 45.80 & 26.50 & na & $90+$ & 6.6 & + & 8.0 & na & Vrancea \\
\hline 158 & 193411 & 30 & 02 & 58 & 16 & 44.10 & 14.00 & na & & 5.6 & + & & na & Croatia \\
\hline 159 & 193509 & 05 & 06 & 00 & & 45.80 & 26.70 & na & $150+$ & 5.5 & & 6.0 & na & Vrancea \\
\hline 160 & 193909 & 05 & 06 & 02 & 0 & 45.90 & 26.70 & na & $115+$ & 5.9 & + & & na & Vrancea \\
\hline 161 & 194006 & 24 & 09 & 57 & 27 & 45.90 & 26.60 & na & $115+$ & 5.5 & + & 5.5 & na & Mt. Háromszék \\
\hline 162 & 194010 & 22 & $06 ?$ & 36 & 57 & 45.76 & 26.42 & na & $122+$ & 6.4 & + & 7.0 & na & Háromszék \\
\hline 163 & 194011 & 10 & $01 ?$ & 39 & 7 & 45.77 & 26.73 & na & $133+$ & 7.3 & + & 9.0 & na & Mt. Háromszék \\
\hline 164 & 194011 & 11 & 06 & 34 & 16 & 46.00 & 26.80 & na & & 5.6 & + & 6.0 & na & Mt. Háromszék \\
\hline 165 & 194011 & 19 & 202 & 27 & 12 & 46.00 & 26.50 & na & & 5.7 & + & 6.0 & na & Mt. Háromszék \\
\hline 166 & 194304 & 28 & 20 & 46 & 50 & 45.80 & 27.10 & na & $66+$ & 5.5 & + & 6.0 & na & Moldavia \\
\hline 167 & 194503 & 12 & 20 & 51 & 47 & 45.60 & 26.40 & na & $125+$ & 5.6 & + & 6.0 & na & Mt. Háromszék \\
\hline 168 & $1945 \quad 09$ & 07 & 15 & 48 & 26 & 45.90 & 26.50 & na & $75+$ & 6.5 & + & 7.5 & na & Vrancea \\
\hline 169 & 194512 & 09 & 06 & 08 & 46 & 45.70 & 26.80 & na & $80+$ & 6.1 & + & 7.0 & na & Vrancea \\
\hline 170 & 194611 & 03 & 18 & 46 & 59 & 45.60 & 26.30 & na & $140+$ & 5.5 & + & 6.0 & na & Mt. Háromszék \\
\hline 171 & 194710 & 17 & 13 & 25 & 20 & 45.70 & 26.60 & na & & 5.8 & + & & na & Mt. Háromszék \\
\hline 172 & 194805 & 29 & 04 & 48 & 58 & 45.80 & 26.50 & na & $140+$ & 5.9 & + & 6.5 & na & Mt. Háromszék \\
\hline 173 & 195006 & 20 & 01 & 18 & 49 & 45.69 & 26.72 & na & $160+$ & 5.5 & + & 6.0 & na & Vrancea \\
\hline 174 & 195601 & 12 & 05 & 46 & 9 & 47.37 & 19.07 & $<+/-10 \mathrm{~km}$ & $14+$ & 5.6 & + & 8.0 & $+/-1$ & Dunaharaszti \\
\hline 175 & 196002 & 17 & 15 & 32 & 50 & 45.57 & 14.25 & $<+/-20 \mathrm{~km}$ & & 5.5 & + & 6.0 & na & Il. Bistrica \\
\hline 176 & 196010 & 13 & 02 & 21 & 25 & 45.70 & 26.40 & na & $160+$ & 5.5 & + & 6.0 & na & Mt. Háromszék \\
\hline 177 & 196404 & 13 & 08 & 30 & 29 & 45.26 & 18.14 & na & 27 & 5.6 & + & 8.0 & na & Croatia \\
\hline 178 & 196805 & 30 & 18 & 15 & 47 & 45.40 & 17.00 & na & & 5.8 & + & & na & Croatia \\
\hline 179 & 196910 & 27 & 08 & 10 & 58 & 44.85 & 17.22 & $<+/-10 \mathrm{~km}$ & 14 & 5.9 & + & 8.0 & na & Bosnia \\
\hline 180 & 197404 & 17 & 01 & 31 & 34 & 45.94 & 21.19 & $<+/-10 \mathrm{~km}$ & $46+$ & 5.6 & + & 6.0 & na & Varjas \\
\hline 181 & 197605 & 06 & 20 & 00 & 12 & 46.27 & 13.25 & na & $20+$ & 6.2 & + & 9.5 & na & Friuli \\
\hline 182 & 197609 & 11 & 16 & 35 & 1 & 46.30 & 13.32 & $<+/-10 \mathrm{~km}$ & $9+$ & 5.6 & + & 9.0 & na & Friuli \\
\hline 183 & 197609 & 15 & 03 & 15 & 19 & 46.27 & 13.15 & $<+/-10 \mathrm{~km}$ & $16+$ & 5.9 & + & 9.0 & na & Friuli \\
\hline 184 & 197609 & 15 & 09 & 21 & 18 & 46.25 & 13.20 & $<+/-10 \mathrm{~km}$ & $21+$ & 5.8 & + & 8.5 & na & Friuli \\
\hline 185 & 197703 & 04 & 192 & 21 & 54 & 45.77 & 26.76 & $<+/-5 \mathrm{~km}$ & $94+$ & 6.1 & + & 9.0 & na & Vrancea \\
\hline 186 & 198108 & 13 & 02 & 58 & 13 & 44.85 & 17.33 & $<+/-5 \mathrm{~km}$ & $16+$ & 5.5 & + & 8.0 & na & Bosnia \\
\hline 187 & 198608 & 30 & 212 & 28 & 36 & 45.54 & 26.31 & $<+/-5 \mathrm{~km}$ & $137+$ & 6.6 & + & 8.0 & na & Mt. Háromszék \\
\hline 188 & 199005 & 30 & 10 & 40 & 6 & 45.85 & 26.66 & $<+/-5 \mathrm{~km}$ & $89+$ & 6.7 & + & 8.0 & na & Mt. Háromszék \\
\hline 189 & 199005 & 31 & 00 & 17 & 48 & 45.81 & 26.77 & $<+/-5 \mathrm{~km}$ & $90+$ & 5.9 & + & & na & Vrancea \\
\hline 190 & 199107 & 18 & 11 & 56 & 31 & 44.90 & 22.41 & $<+/-5 \mathrm{~km}$ & $12+$ & 5.5 & + & 8.0 & na & Orsova \\
\hline
\end{tabular}


Table 2

Focal mechanism solutions for the Pannonian Region $(44.0-50.0 \mathrm{~N} ; 13.0-28.0 \mathrm{E})$. The parameters of focal mechanisms are given by orientation of $1^{\text {st }}$ nodal plane (angles of strike, dip and rake) and $\mathrm{P}$ and $\mathrm{T}$ axis (angles of azimuth and plunge) followed the convention by Aki and Richards (1980). Quality definition is given by quality designation (A, B, C, D or E, where A is better quality than E) as defined by Zoback and Zoback (1991). Source of data: No. 1 - 162 collected and catalogued from literature by Gerner (1995), new solutions for events from 1980 to 1993 by Gerner et al. (1999); latest solutions for mainly Pannonian Basin events from 1995 to 1998 (No. 163 - 190) by Tóth et al. $(1996,1997,1998,1999)$

\begin{tabular}{|c|c|c|c|c|c|c|c|c|c|c|c|c|}
\hline \multirow{2}{*}{ No. } & \multirow{2}{*}{ Date } & \multirow{2}{*}{ Time } & \multirow{2}{*}{$\begin{array}{l}\text { Lat } \\
(\mathrm{N})\end{array}$} & \multirow{2}{*}{$\begin{array}{c}\text { Long } \\
\text { (E) }\end{array}$} & \multicolumn{3}{|c|}{ Plane 1} & \multicolumn{2}{|c|}{$P$ axis } & \multicolumn{2}{|c|}{ T axis } & \multirow{2}{*}{ Qual. } \\
\hline & & & & & Srike & Dip & Rake & Azim & Plunge & Azim & Plunge & \\
\hline 1 & 1928.03.27 & $8: 32: 31$ & 46.42 & 13.03 & 298 & 67 & 148 & 351 & 4 & 258 & 38 & $\mathrm{D}$ \\
\hline 2 & 1929.11 .01 & $6: 57: 21$ & 45.90 & 26.60 & 171 & 60 & 106 & 249 & 14 & 116 & 70 & $\mathrm{E}$ \\
\hline 3 & 1934.01.29 & & 45.70 & 26.50 & 71 & 62 & -146 & 287 & 43 & 197 & 1 & $\mathrm{E}$ \\
\hline 4 & 1934.03 .24 & & 45.80 & 26.50 & 73 & 61 & -145 & 289 & 44 & 199 & 1 & $\mathrm{E}$ \\
\hline 5 & 1934.03 .29 & $20: 06: 48$ & 45.80 & 26.50 & 200 & 66 & 129 & 263 & 12 & 157 & 52 & $\mathrm{E}$ \\
\hline 6 & 1934.11 .30 & $2: 58: 19$ & 44.10 & 14.00 & 30 & 88 & -22 & 343 & 17 & 77 & 14 & $\mathrm{D}$ \\
\hline 7 & 1935.07 .13 & $0: 03: 46$ & 46.00 & 26.50 & 33 & 90 & -90 & 303 & 45 & 123 & 45 & $\mathrm{E}$ \\
\hline 8 & 1935.08 .13 & & 45.70 & 27.70 & 220 & 58 & 74 & 321 & 12 & 92 & 72 & $\mathrm{E}$ \\
\hline 9 & 1938.03 .27 & $11: 16: 24$ & 46.20 & 16.80 & 310 & 80 & 90 & 40 & 35 & 220 & 55 & $\mathrm{D}$ \\
\hline 10 & 1940.06 .24 & 09:17: & 45.90 & 26.60 & 220 & 58 & 94 & 307 & 13 & 143 & 76 & $\mathrm{E}$ \\
\hline 11 & 1940.10 .22 & $6: 36: 57$ & 45.80 & 26.40 & 223 & 61 & 87 & 315 & 16 & 125 & 74 & $\mathrm{E}$ \\
\hline 12 & 1940.11 .10 & $1: 39: 07$ & 45.80 & 26.70 & 224 & 62 & 75 & 325 & 16 & 104 & 69 & $\mathrm{E}$ \\
\hline 13 & 1940.11 .11 & $6: 34: 17$ & 46.00 & 26.80 & 216 & 56 & 94 & 303 & 11 & 140 & 78 & $\mathrm{E}$ \\
\hline 14 & 1945.03 .12 & & 45.70 & 26.80 & 223 & 56 & -83 & 159 & 78 & 308 & 11 & E \\
\hline 15 & 1945.09 .07 & $15: 48: 22$ & 45.90 & 26.50 & 224 & 60 & 93 & 312 & 15 & 141 & 75 & E \\
\hline 16 & 1945.12 .09 & $6: 08: 45$ & 45.70 & 26.80 & 134 & 63 & -115 & 3 & 63 & 242 & 15 & $\mathrm{E}$ \\
\hline 17 & 1948.05 .29 & $4: 48: 55$ & 45.80 & 26.50 & 196 & 48 & 84 & 290 & 3 & 54 & 85 & $\mathrm{E}$ \\
\hline 18 & 1950.05 .01 & & 45.50 & 26.30 & 317 & 49 & 69 & 62 & 2 & 160 & 74 & $\mathrm{E}$ \\
\hline 19 & 1950.06 .20 & $1: 18: 47$ & 45.90 & 26.50 & 260 & 90 & -110 & 151 & 42 & 9 & 42 & $\mathrm{E}$ \\
\hline 20 & 1952.06 .03 & $5: 53: 22$ & 45.70 & 26.80 & 10 & 54 & 67 & 116 & 6 & 224 & 71 & $\mathrm{D}$ \\
\hline 21 & 1954.10 .01 & 13:30: & 45.50 & 27.10 & 60 & 70 & -101 & 313 & 63 & 158 & 24 & $\mathrm{D}$ \\
\hline 22 & 1955.02 .01 & $21: 22:$ & 45.50 & 26.30 & 347 & 61 & 134 & 47 & 6 & 310 & 52 & $\mathrm{E}$ \\
\hline 23 & 1956.01 .12 & $5: 46: \overline{08}$ & 47.35 & 19.09 & 85 & 73 & 160 & 133 & 2 & 42 & 26 & $\mathrm{~B}$ \\
\hline 24 & 1956.04.18 & $12: 52:$ & 46.10 & 27.40 & 162 & 77 & 74 & 265 & 30 & 53 & 55 & $\mathrm{C}$ \\
\hline 25 & 1956.11 .05 & & 46.50 & 13.08 & 280 & 90 & -179 & 145 & 1 & 55 & 1 & $\mathrm{E}$ \\
\hline 26 & 1957.12 .23 & $23: 38:$ & 45.40 & 26.90 & 7 & 56 & -112 & 228 & 70 & 112 & 8 & $\mathrm{C}$ \\
\hline 27 & 1959.04.26 & $14: 45: \overline{16}$ & 46.46 & 13.00 & 304 & 76 & -161 & 168 & 23 & 75 & 3 & $\mathrm{C}$ \\
\hline 28 & 1959.05.31 & $12: 15: 43$ & 45.70 & 27.20 & 149 & 84 & -106 & 42 & 48 & 253 & 37 & $\mathrm{E}$ \\
\hline 29 & 1959.05.31 & $23: 38:$ & 45.89 & 27.39 & 20 & 70 & -80 & 307 & 64 & 102 & 24 & $\mathrm{D}$ \\
\hline 30 & 1959.06 .26 & $13: 44: \overline{40}$ & 45.86 & 26.53 & 80 & 60 & 141 & 137 & 2 & 45 & 48 & $\mathrm{E}$ \\
\hline 31 & 1960.01 .04 & 12:21: & 44.60 & 27.00 & 271 & 60 & -118 & 133 & 63 & 21 & 11 & $\mathrm{C}$ \\
\hline 32 & 1960.01 .26 & $20: 27: \overline{04}$ & 45.80 & 26.80 & 332 & 58 & 88 & 63 & 13 & 237 & 77 & $\mathrm{E}$ \\
\hline 33 & 1960.10 .13 & $2: 21: 25$ & 45.70 & 26.40 & 343 & 50 & 90 & 73 & 5 & 253 & 85 & $\mathrm{E}$ \\
\hline 34 & 1961.11 .18 & 03:18: & 45.50 & 26.70 & 165 & 87 & 90 & 255 & 42 & 75 & 48 & $\mathrm{E}$ \\
\hline 35 & 1962.02 .27 & $21: 34:$ & 45.70 & 26.40 & 358 & 80 & 78 & 98 & 34 & 254 & 54 & $\mathrm{E}$ \\
\hline 36 & 1962.08 .30 & $7: 46: \overline{00}$ & 45.50 & 26.70 & 345 & 65 & 94 & 72 & 20 & 264 & 70 & $\mathrm{E}$ \\
\hline 37 & 1962.11 .09 & $2: 14: 52$ & 45.80 & 26.70 & 132 & 47 & -108 & 328 & 77 & 234 & 1 & $\mathrm{E}$ \\
\hline 38 & 1963.01 .14 & $18: 33: 24$ & 45.70 & 26.60 & 326 & 54 & -90 & 236 & 81 & 56 & 9 & $\mathrm{E}$ \\
\hline 39 & 1963.02 .14 & $13: 18: 57$ & 44.33 & 15.12 & 235 & 70 & -35 & 193 & 39 & 289 & 8 & $\mathrm{D}$ \\
\hline 40 & 1963.05 .19 & 10:00:08 & 46.27 & 14.53 & 304 & 60 & 91 & 33 & 15 & 217 & 75 & $\mathrm{C}$ \\
\hline 41 & 1963.12 .02 & $6: 49: 05$ & 48.03 & 16.20 & 0 & 70 & 90 & 90 & 25 & 270 & 65 & $\mathrm{D}$ \\
\hline 42 & 1964.04 .13 & 08:29:59 & 45.30 & 18.10 & 302 & 55 & 101 & 24 & 10 & 247 & 77 & $\mathrm{~B}$ \\
\hline 43 & 1964.06 .30 & $12: 29: 59$ & 47.73 & 15.92 & 92 & 90 & -1 & 47 & 1 & 137 & 1 & $\mathrm{D}$ \\
\hline 44 & 1964.10 .27 & $19: 46: 09$ & 47.85 & 15.95 & 245 & 80 & -42 & 196 & 36 & 301 & 20 & $\mathrm{D}$ \\
\hline 45 & 1965.01 .10 & $02: 52: 25$ & 45.80 & 26.60 & 348 & 50 & 98 & 72 & 5 & 306 & 82 & $\mathrm{E}$ \\
\hline 46 & 1966.09.04 & 01:29:29 & 45.77 & 26.63 & 5 & 90 & -106 & 260 & 43 & 110 & 43 & $\mathrm{E}$ \\
\hline
\end{tabular}


Table 2 (Cont.)

\begin{tabular}{|c|c|c|c|c|c|c|c|c|c|c|c|c|}
\hline \multirow{2}{*}{ No. } & \multirow{2}{*}{ Date } & \multirow{2}{*}{ Time } & \multirow{2}{*}{$\begin{array}{l}\text { Lat } \\
(\mathbf{N})\end{array}$} & \multirow{2}{*}{$\begin{array}{c}\text { Long } \\
\text { (E) }\end{array}$} & \multicolumn{3}{|c|}{ Plane 1} & \multicolumn{2}{|c|}{$P$ axis } & \multicolumn{2}{|c|}{$T$ axis } & \multirow{2}{*}{ Qual } \\
\hline & & & & & Srike & Dip & Rake & Azim & Plunge & Azim & Plunge & \\
\hline 47 & 1966.10 .02 & $11: 21: 45$ & 45.77 & 26.50 & 5 & 50 & 90 & 95 & 5 & 275 & 85 & $\mathrm{E}$ \\
\hline 48 & 1966.10 .15 & $06: 59: 19$ & 45.60 & 26.40 & 134 & 84 & 93 & 221 & 39 & 48 & 51 & $\mathrm{E}$ \\
\hline 49 & 1966.12 .14 & $14: 49: 59$ & 45.72 & 26.39 & 165 & 48 & 90 & 255 & 3 & 75 & 87 & $\mathrm{E}$ \\
\hline 50 & 1966.12 .29 & 06:30:02 & 45.54 & 26.48 & 158 & 63 & 65 & 266 & 15 & 27 & 63 & $\mathrm{E}$ \\
\hline 51 & 1967.01 .29 & & 47.91 & 14.26 & 105 & 71 & -84 & 25 & 63 & 190 & 26 & $\mathrm{D}$ \\
\hline 52 & 1967.02 .27 & $21: 00: 42$ & 44.86 & 26.69 & 187 & 71 & -32 & 145 & 36 & 239 & 8 & $\mathrm{D}$ \\
\hline 53 & 1968.01 .06 & $10: 23: 50$ & 45.76 & 26.46 & 160 & 67 & -44 & 118 & 47 & 219 & 10 & $\mathrm{E}$ \\
\hline 54 & 1968.02 .09 & $13: 22: 54$ & 45.61 & 26.42 & 220 & 62 & 68 & 326 & 14 & 90 & 66 & $\mathrm{E}$ \\
\hline 55 & 1968.10 .20 & $23: 15: 04$ & 45.81 & 26.59 & 129 & 60 & 73 & 231 & 13 & 3 & 70 & $\mathrm{E}$ \\
\hline 56 & 1968.11 .20 & $01: 51: 15$ & 45.65 & 26.60 & 345 & 80 & 91 & 74 & 35 & 257 & 55 & $\mathrm{E}$ \\
\hline 57 & 1969.01 .15 & $08: 46: 29$ & 45.62 & 26.55 & 344 & 55 & 106 & 62 & 8 & 300 & 74 & $\mathrm{E}$ \\
\hline 58 & 1969.04 .12 & $20: 38: 41$ & 45.30 & 25.10 & 137 & 83 & -31 & 90 & 26 & 188 & 16 & $\mathrm{C}$ \\
\hline 59 & 1969.06 .01 & $23: 20: 29$ & 47.00 & 14.20 & 94 & 78 & 159 & 143 & 6 & 50 & 23 & $\mathrm{C}$ \\
\hline 60 & 1969.10 .26 & $15: 36: 51$ & 44.87 & 17.28 & 228 & 88 & 12 & 2 & 7 & 94 & 10 & $\mathrm{D}$ \\
\hline 61 & 1969.10 .27 & $2: 55: 34$ & 44.98 & 17.04 & 285 & 50 & 90 & 15 & 5 & 195 & 85 & $\mathrm{D}$ \\
\hline 62 & 1969.10 .27 & 08:10:58 & 44.92 & 17.23 & 246 & 90 & -1 & 201 & 1 & 291 & 1 & $\mathrm{~B}$ \\
\hline 63 & 1969.12 .31 & $13: 18: 33$ & 44.88 & 17.23 & 160 & 70 & -128 & 28 & 50 & 277 & 16 & $\mathrm{C}$ \\
\hline 64 & 1970.07 .10 & & 47.90 & 26.90 & 193 & 61 & 94 & 280 & 16 & 113 & 74 & $\mathrm{D}$ \\
\hline 65 & 1971.07 .18 & $16: 18: 22$ & 45.71 & 26.31 & 131 & 58 & 43 & 252 & 2 & 345 & 51 & $\mathrm{E}$ \\
\hline 66 & 1972.01 .05 & & 47.80 & 16.25 & 145 & 80 & 169 & 191 & 1 & 101 & 15 & $\mathrm{D}$ \\
\hline 67 & 1972.04 .16 & $00: 03: 31$ & 45.53 & 26.44 & 55 & 74 & 105 & 133 & 28 & 346 & 58 & $\mathrm{E}$ \\
\hline 68 & 1972.04 .16 & 10:10:03 & 47.73 & 16.12 & 205 & 90 & -20 & 158 & 14 & 252 & 14 & $\mathrm{C}$ \\
\hline 69 & 1972.04 .16 & $11: 04: 44$ & 47.73 & 16.02 & 235 & 77 & 26 & 5 & 8 & 100 & 27 & $\mathrm{D}$ \\
\hline 70 & 1973.08 .20 & $15: 18:$ & 45.70 & 26.50 & 26 & 78 & 71 & 132 & 31 & 274 & 53 & $\mathrm{E}$ \\
\hline 71 & 1973.10 .23 & 10:50: & 45.70 & 26.50 & 117 & 56 & 70 & 222 & 9 & 338 & 71 & $\mathrm{E}$ \\
\hline 72 & 1973.12 .12 & $0: 02: \overline{38}$ & 47.05 & 14.10 & 264 & 87 & 160 & 311 & 12 & 218 & 16 & $\mathrm{C}$ \\
\hline 73 & 1974.06 .20 & $17: 08: 28$ & 46.16 & 15.57 & 81 & 89 & -40 & 29 & 28 & 134 & 26 & $\mathrm{E}$ \\
\hline 74 & 1974.06 .20 & $17: 08: 47$ & 46.20 & 15.91 & 358 & 58 & -120 & 210 & 64 & 110 & 10 & $\mathrm{C}$ \\
\hline 75 & 1974.06 .20 & $22: 26: 31$ & 46.19 & 15.53 & 240 & 51 & 66 & 347 & 3 & 87 & 71 & $\mathrm{C}$ \\
\hline 76 & 1974.07 .17 & 05:09:_ & 45.80 & 26.50 & 82 & 72 & 109 & 158 & 24 & 18 & 59 & $\mathrm{E}$ \\
\hline 77 & 1975.02 .08 & 08:21: & 45.10 & 26.00 & 144 & 74 & 21 & 275 & 3 & 7 & 26 & $\mathrm{C}$ \\
\hline 78 & 1975.03 .07 & $04: 13:$ & 45.90 & 26.60 & 237 & 83 & 31 & 6 & 16 & 104 & 26 & $\mathrm{C}$ \\
\hline 79 & 1976-1979 & & 46.30 & 13.25 & 87 & 63 & 98 & 171 & 18 & 14 & 71 & A \\
\hline 80 & 1976.05 .06 & 19:59:06 & 46.27 & 13.31 & 86 & 72 & 104 & 165 & 26 & 17 & 61 & $\mathrm{E}$ \\
\hline 81 & 1976.05 .06 & 20:00:11 & 46.27 & 13.27 & 77 & 70 & 103 & 157 & 24 & 7 & 63 & $\mathrm{E}$ \\
\hline 82 & 1976.05 .07 & $0: 23: 50$ & 46.26 & 13.32 & 87 & 70 & 121 & 154 & 19 & 35 & 54 & $\mathrm{E}$ \\
\hline 83 & 1976.05 .08 & $3: 10: 06$ & 46.26 & 13.19 & 83 & 59 & 95 & 170 & 14 & 7 & 76 & $\mathrm{E}$ \\
\hline 84 & 1976.05 .09 & $0: 53: 45$ & 46.21 & 13.30 & 101 & 56 & 99 & 185 & 10 & 40 & 77 & $\mathrm{C}$ \\
\hline 85 & 1976.05 .10 & $4: 35: 52$ & 46.24 & 13.15 & 72 & 63 & 94 & 159 & 18 & 352 & 71 & $\mathrm{E}$ \\
\hline 86 & 1976.05 .11 & $22: 44: 01$ & 46.24 & 13.04 & 95 & 63 & 107 & 172 & 17 & 38 & 67 & $\mathrm{C}$ \\
\hline 87 & 1976.06 .08 & $12: 14: 38$ & 46.30 & 13.24 & 102 & 61 & 127 & 167 & 9 & 63 & 57 & $\mathrm{E}$ \\
\hline 88 & 1976.06 .26 & $11: 13: 47$ & 46.26 & 13.13 & 90 & 71 & 119 & 158 & 21 & 36 & 54 & $\mathrm{E}$ \\
\hline 89 & 1976.07 .14 & $5: 39: 34$ & 46.34 & 13.29 & 103 & 63 & 128 & 167 & 10 & 62 & 55 & $\mathrm{E}$ \\
\hline 90 & 1976.09 .11 & $16: 31: 11$ & 46.28 & 13.21 & 82 & 61 & 113 & 155 & 13 & 35 & 66 & $\mathrm{E}$ \\
\hline 91 & 1976.09 .11 & $16: 35: 02$ & 46.27 & 13.26 & 77 & 76 & 98 & 161 & 31 & 358 & 58 & $\mathrm{E}$ \\
\hline 92 & 1976.09 .12 & $19: 53: 28$ & 46.30 & 13.21 & 89 & 66 & 98 & 173 & 20 & 14 & 68 & $\mathrm{E}$ \\
\hline 93 & 1976.09 .13 & $18: 54: 46$ & 46.29 & 13.20 & 97 & 65 & 127 & 161 & 12 & 54 & 54 & $\mathrm{E}$ \\
\hline 94 & 1976.09 .15 & $03: 15: 19$ & 46.30 & 13.19 & 46 & 59 & 63 & 155 & 10 & 268 & 65 & $\mathrm{E}$ \\
\hline 95 & 1976.09 .15 & $4: 38: 54$ & 46.29 & 13.16 & 52 & 80 & 101 & 133 & 34 & 335 & 53 & $\mathrm{E}$ \\
\hline 96 & 1976.09 .15 & 09:21:19 & 46.32 & 13.13 & 61 & 68 & 61 & 172 & 18 & 292 & 57 & $\mathrm{E}$ \\
\hline 97 & 1976.09 .15 & $9: 45: 57$ & 46.29 & 13.29 & 102 & 63 & 135 & 162 & 7 & 63 & 50 & $\mathrm{E}$ \\
\hline 98 & 1976.09 .15 & $19: 31: 11$ & 46.29 & 13.18 & 98 & 62 & 115 & 170 & 14 & 51 & 64 & $\mathrm{E}$ \\
\hline 99 & 1976.10 .01 & 17:50: & 45.70 & 26.50 & 334 & 48 & 80 & 71 & 3 & 178 & 82 & $\mathrm{E}$ \\
\hline 100 & 1977.03 .04 & $19: 21: 54$ & 45.80 & 26.80 & 238 & 76 & 106 & 315 & 29 & 168 & 56 & $\mathrm{E}$ \\
\hline 101 & 1977.03 .05 & 00:00: & 45.30 & 27.10 & 106 & 86 & 37 & 234 & 22 & 336 & 28 & $\mathrm{D}$ \\
\hline
\end{tabular}


Table 2 (Cont.)

\begin{tabular}{|c|c|c|c|c|c|c|c|c|c|c|c|c|}
\hline \multirow{2}{*}{ No. } & \multirow{2}{*}{ Date } & \multirow{2}{*}{ Time } & \multirow{2}{*}{$\begin{array}{l}\text { Lat } \\
\text { (N) }\end{array}$} & \multirow{2}{*}{$\begin{array}{l}\text { Long } \\
\text { (E) }\end{array}$} & \multicolumn{3}{|c|}{ Plane 1} & \multicolumn{2}{|c|}{$P$ axis } & \multicolumn{2}{|c|}{$T$ axis } & \\
\hline & & & & & Srike & Dip & Rake & Azim & Plunge & Azim & Plunge & \\
\hline 102 & 1977.04 .03 & $3: 18: 14$ & 46.29 & 13.16 & 142 & 60 & 100 & 225 & 14 & 77 & 73 & $\mathrm{E}$ \\
\hline 103 & 1977.07.16 & 13:13:31 & 46.31 & 14.36 & 348 & 72 & 90 & 78 & 27 & 257 & 63 & C \\
\hline 104 & 1977.09 .16 & $23: 48: 08$ & 46.25 & 13.00 & 92 & 72 & 106 & 170 & 25 & 25 & 60 & $\Gamma$ \\
\hline 105 & 1978.02 .20 & $12: 13: 34$ & 46.44 & 13.27 & 95 & 90 & -80 & 15 & 44 & 175 & 44 & \\
\hline 106 & 1978.04 .03 & 10:49:46 & 46.29 & 13.17 & 145 & 57 & 117 & 216 & 8 & 107 & 66 & \\
\hline 107 & 1978.04 .23 & 11:23:04 & 46.08 & 13.59 & 175 & 81 & -72 & 105 & 51 & 250 & 33 & \\
\hline 108 & 1978.06.22 & 02:33: & 46.75 & 21.13 & 355 & 79 & -144 & 222 & 33 & 121 & 16 & \\
\hline 109 & 1978.06 .22 & $2: 57: 54$ & 46.75 & 21.13 & 266 & 70 & 42 & 29 & 12 & 130 & 43 & \\
\hline 110 & 1978.10 .02 & $20: 28: 52$ & 45.70 & 26.70 & 316 & 56 & 93 & 44 & 11 & 236 & 79 & \\
\hline 111 & 1979.03 .06 & $13: 46: 06$ & 46.40 & 13.02 & 293 & 52 & 76 & 33 & 6 & 151 & 77 & \\
\hline 112 & 1979.03 .08 & & 47.82 & 23.31 & 24 & 50 & 102 & 106 & 5 & 349 & 80 & \\
\hline 113 & 1979.03 .30 & & 47.68 & 23.22 & 108 & 65 & -47 & 64 & 50 & 170 & 8 & \\
\hline 114 & 1979.04 .18 & $15: 19: 20$ & 46.33 & 13.31 & 315 & 61 & 143 & 11 & 2 & 280 & 46 & \\
\hline 115 & 1979.05 .31 & 07:20:06 & 45.60 & 26.40 & 233 & 80 & 65 & 344 & 31 & 116 & 49 & \\
\hline 116 & 1979.06 .19 & 10:03:15 & 46.28 & 13.20 & 83 & 72 & -53 & 33 & 49 & 146 & 19 & \\
\hline 117 & 1979.08 .14 & $18: 58: 58$ & 46.32 & 13.04 & 8 & 82 & 43 & 133 & 23 & 238 & 36 & \\
\hline 118 & 1979.09 .11 & $15: 36: 54$ & 45.60 & 26.50 & 12 & 77 & 86 & 105 & 32 & 277 & 58 & \\
\hline 119 & 1980.03 .25 & & 47.50 & 20.10 & 125 & 66 & 137 & 183 & 9 & 84 & 47 & \\
\hline 120 & 1980.12 .08 & 19:51: & 44.40 & 27.20 & 331 & 89 & 45 & 96 & 29 & 205 & 31 & \\
\hline 121 & 981.06 .28 & $06: 16: 27$ & 45.68 & 14.14 & 52 & 90 & -1 & 7 & 1 & 97 & 1 & \\
\hline 122 & 1981.07.18 & 00:03:_ & 45.70 & 26.40 & 92 & 89 & 135 & 147 & 29 & 38 & 31 & \\
\hline 123 & 1981.08 .13 & 02:58:11 & 44.84 & 17.31 & 71 & 83 & -31 & 24 & 26 & 122 & 16 & \\
\hline 124 & 1982.05 .16 & 04:03: & 45.40 & 26.40 & 206 & 81 & -15 & 161 & 17 & 253 & 4 & \\
\hline 125 & 1982.06 .05 & $17: 54: 12$ & 45.70 & 8 & 124 & 80 & 140 & 178 & 20 & 77 & 35 & \\
\hline 126 & 1982.07.01 & & 48.48 & 22.23 & 140 & 50 & 96 & 226 & 5 & 87 & 83 & \\
\hline 127 & 1983.01 .25 & 07:34: & 45.70 & 26.70 & 323 & 58 & 131 & 25 & 5 & 288 & 56 & \\
\hline 128 & 1983. & 18:03: & 45.30 & 27.10 & 234 & 63 & 108 & 311 & 16 & 178 & 67 & \\
\hline 129 & 1983.02.26 & 00:57: & 45.6 & 3 & 258 & 89 & 110 & 329 & 41 & 187 & 42 & \\
\hline 130 & 1983.04 .14 & $14: 52: 14$ & 47.6 & 14 & 67 & 90 & -1 & 22 & 1 & 112 & 1 & \\
\hline 131 & 1983.04 .24 & 06:56: & 45.6 & 66 & 155 & 66 & 98 & 239 & 21 & 80 & 68 & \\
\hline 132 & 1983.08 .05 & $15: 50: 50$ & 45.9 & 7 & 95 & 90 & -39 & 42 & 26 & 147 & 26 & \\
\hline 133 & 1983.08 .25 & $23: 57$ & 45.6 & 2 & 258 & 80 & 107 & 333 & 33 & 188 & 52 & \\
\hline 134 & 1983.12 .20 & $08: 26: 47$ & 46. & 1 & 7 & 54 & 52 & 3 & 2 & 97 & 60 & \\
\hline 135 & 1984.10 .25 & $13: 5$ & 5.6 & 3 & 302 & 89 & -96 & 206 & 45 & 38 & 44 & \\
\hline 136 & 1984.11 .30 & $22: 25:$ & 45.69 & 2 & 245 & 53 & 128 & 310 & 1 & 218 & 61 & \\
\hline 137 & 1985.08.01 & $14: 35: 03$ & 45.80 & 2 & 200 & 76 & 150 & 252 & 10 & 156 & 31 & \\
\hline 138 & 1985.08 .15 & $04: 28: 47$ & 47.06 & 1 & 224 & 76 & -163 & 88 & 22 & 356 & 1 & B \\
\hline 139 & 1986.02 .09 & $17: 51: 38$ & 46.37 & 1 & 279 & 63 & 128 & 343 & 10 & 238 & 55 & \\
\hline 140 & 1986.04.27 & 00:04: & 45.50 & 27.10 & 30 & 47 & 79 & 128 & 2 & 228 & 82 & \\
\hline 141 & 1986.04.27 & 00:47: & 45.50 & 27.10 & 294 & 62 & -115 & 161 & 64 & 42 & 13 & \\
\hline 142 & 1986.08 .30 & $21: 28: 35$ & 45.50 & 26.50 & 235 & 66 & 82 & 331 & 21 & 131 & 68 & \\
\hline 143 & 1986.11 .25 & $13: 59: 42$ & 44.14 & 16.41 & 89 & 70 & 83 & 185 & 25 & 348 & 64 & \\
\hline 144 & 1986.12.16 & $06: 22: 49$ & 45.07 & 14.83 & 41 & 50 & 61 & 151 & 1 & 243 & 68 & \\
\hline 145 & 1988.11 .29 & $1: 23: 38$ & 45.70 & 21.50 & 344 & 85 & -32 & 296 & 26 & 35 & 18 & \\
\hline 146 & 1989.01.26 & 09:42:57 & 47.03 & 16.98 & 77 & 78 & -147 & 303 & 32 & 205 & 13 & \\
\hline 147 & 1989.01.27 & $02: 55: 03$ & 47.04 & 16.87 & 155 & 50 & -121 & 358 & 67 & 266 & 1 & \\
\hline 148 & 1989.08.18 & $7: 26: 25$ & 45.9 & 26.82 & 223 & 85 & 169 & 269 & 4 & 178 & 11 & \\
\hline 149 & 1990.05 .30 & 10:40:06 & 45.8 & 26.67 & 236 & 63 & 101 & 318 & 17 & 168 & 70 & \\
\hline 150 & 1990.05 .31 & 00:17:47 & 45.80 & 26.75 & 309 & 69 & 106 & 27 & 22 & 244 & 63 & \\
\hline 151 & 1991.04 .27 & $18: 44: 53$ & 46.5 & 15.19 & 125 & 75 & 90 & 215 & 30 & 35 & 60 & \\
\hline 152 & 1991.07.12 & $10: 42: 21$ & 45.35 & 20.98 & 125 & 80 & 40 & 250 & 19 & 354 & 35 & \\
\hline 153 & 1991.07.14 & $23: 59: 31$ & 45.43 & 21.12 & 175 & 57 & -123 & 30 & 62 & 288 & 7 & \\
\hline 154 & 1991.07.18 & $11: 56: 30$ & 44.90 & 22.35 & 58 & 57 & -137 & 270 & 52 & 179 & 1 & \\
\hline 155 & 991.07 .19 & $01: 27: 33$ & 45.34 & 21.04 & 199 & 77 & -163 & 63 & 21 & 332 & 3 & \\
\hline 156 & 1991.08 .14 & $23: 26:$ & 45.52 & 21.22 & 6 & 46 & 98 & 90 & 1 & 351 & 84 & \\
\hline
\end{tabular}


Table 2 (Cont.)

\begin{tabular}{|c|c|c|c|c|c|c|c|c|c|c|c|c|}
\hline \multirow{2}{*}{ No. } & \multirow{2}{*}{ Date } & \multirow{2}{*}{ Time } & \multirow{2}{*}{$\begin{array}{l}\text { Lat } \\
(\mathrm{N})\end{array}$} & \multirow{2}{*}{$\begin{array}{c}\text { Long } \\
\text { (E) }\end{array}$} & \multicolumn{3}{|c|}{ Plane 1} & \multicolumn{2}{|c|}{$P$ axis } & \multicolumn{2}{|c|}{ T axis } & \multirow{2}{*}{ Qual. } \\
\hline & & & & & Srike & Dip & Rake & Azim & Plunge & Azim & Plunge & \\
\hline 157 & 1991.09 .01 & 01:16:03 & 45.47 & 26.91 & 242 & 74 & -143 & 107 & 37 & 7 & 12 & B \\
\hline 158 & 1991.09 .17 & 03:02:01 & 44.54 & 22.42 & 150 & 65 & -139 & 10 & 46 & 273 & 7 & D \\
\hline 159 & 1991.12 .02 & $08: 49: 40$ & 45.48 & 21.12 & 194 & 85 & -162 & 60 & 16 & 327 & 9 & $\mathrm{C}$ \\
\hline 160 & 1992.02 .21 & $20: 50: 32$ & 45.46 & 14.32 & 156 & 60 & 110 & 231 & 13 & 107 & 68 & D \\
\hline 161 & 1993.05 .23 & $17: 19: 23$ & 45.36 & 25.51 & 335 & 90 & -10 & 290 & 7 & 20 & 7 & $\mathrm{C}$ \\
\hline 162 & 1993.06 .01 & $19: 51: 10$ & 46.16 & 16.46 & 332 & 84 & 129 & 32 & 28 & 277 & 38 & D \\
\hline 163 & 1995.09 .12 & $22: 14: 05$ & 47.22 & 18.14 & 260 & 81 & 30 & 29 & 14 & 127 & 27 & $\mathrm{C}$ \\
\hline 164 & 1995.09 .18 & $8: 26: 10$ & 47.89 & 18.87 & 120 & 75 & -80 & 44 & 59 & 202 & 29 & D \\
\hline 165 & 1996.01 .09 & $1: 07: 22$ & 47.96 & 16.49 & 169 & 72 & 27 & 298 & 5 & 31 & 31 & $\mathrm{C}$ \\
\hline 166 & 1996.03 .28 & $6: 31: 22$ & 46.91 & 19.25 & 90 & 75 & -20 & 47 & 25 & 138 & 3 & $\mathrm{C}$ \\
\hline 167 & 1996.09 .29 & $21: 45: 53$ & 47.30 & 21.37 & 235 & 81 & -95 & 139 & 53 & 329 & 36 & $\mathrm{C}$ \\
\hline 168 & 1996.10 .03 & $22: 41: 00$ & 46.17 & 15.11 & 219 & 72 & 27 & 348 & 5 & 81 & 31 & D \\
\hline 169 & 1996.12 .03 & $0: 30: 57$ & 47.73 & 16.10 & 355 & 80 & -120 & 234 & 47 & 109 & 29 & $\mathrm{D}$ \\
\hline 170 & 1997.01.27 & $0: 46: 13$ & 44.86 & 16.11 & 320 & 75 & -160 & 183 & 25 & 92 & 3 & D \\
\hline 171 & 1997.03 .08 & $18: 53: 39$ & 45.89 & 15.72 & 235 & 90 & -20 & 188 & 14 & 282 & 14 & D \\
\hline 172 & 1997.03 .30 & 4:18:04 & 47.75 & 16.17 & 285 & 90 & -25 & 237 & 17 & 333 & 17 & D \\
\hline 173 & 1997.05 .10 & $19: 29: 14$ & 48.09 & 16.70 & 321 & 72 & 153 & 12 & 5 & 279 & 31 & D \\
\hline 174 & 1997.05 .30 & $19: 28: 20$ & 47.72 & 16.05 & 310 & 75 & -140 & 176 & 38 & 74 & 15 & $\mathrm{C}$ \\
\hline 175 & 1997.06 .03 & 21:01:59 & 47.73 & 15.90 & 160 & 80 & 160 & 208 & 7 & 115 & 21 & D \\
\hline 176 & 1997.06.17 & $13: 33: 45$ & 46.45 & 20.72 & 350 & 55 & -130 & 201 & 58 & 107 & 2 & $\mathrm{C}$ \\
\hline 177 & 1997.07.16 & $20: 43: 31$ & 47.78 & 17.30 & 170 & 90 & -150 & 39 & 21 & 301 & 21 & D \\
\hline 178 & 1997.09 .04 & $1: 45: 39$ & 47.71 & 16.16 & 132 & 80 & -170 & 356 & 14 & 266 & 0 & D \\
\hline 179 & 1997.11 .27 & $10: 40: 56$ & 47.26 & 19.38 & 45 & 55 & -110 & 264 & 72 & 149 & 8 & D \\
\hline 180 & 1998.01 .18 & 7:30:08 & 46.03 & 16.93 & 165 & 80 & 150 & 216 & 13 & 119 & 28 & D \\
\hline 181 & 1998.02 .26 & $12: 09: 22$ & 44.92 & 17.92 & 210 & 90 & -30 & 161 & 21 & 259 & 21 & D \\
\hline 182 & 1998.03.11 & $11: 33: 28$ & 47.93 & 16.42 & 120 & 70 & -30 & 78 & 35 & 172 & 5 & D \\
\hline 183 & 1998.04 .12 & $10: 55: 36$ & 46.28 & 13.63 & 130 & 85 & 160 & 178 & 10 & 84 & 18 & $\mathrm{C}$ \\
\hline 184 & 1998.04 .15 & $22: 42: 11$ & 46.31 & 13.76 & 20 & 80 & -140 & 249 & 35 & 145 & 19 & D \\
\hline 185 & 1998.05.08 & $4: 06: 54$ & 47.51 & 18.93 & 155 & 55 & 130 & 218 & 2 & 124 & 58 & $\mathrm{D}$ \\
\hline 186 & 1998.05.27 & $12: 35: 45$ & 46.10 & 16.71 & 315 & 85 & -150 & 183 & 24 & 85 & 17 & D \\
\hline 187 & 1998.06 .02 & $20: 46: 50$ & 46.59 & 14.33 & 150 & 60 & -110 & 19 & 68 & 254 & 13 & $\mathrm{C}$ \\
\hline 188 & 1998.06 .28 & $12: 19: 40$ & 47.49 & 18.92 & 60 & 75 & -80 & 344 & 59 & 142 & 29 & D \\
\hline 189 & 1998.07 .05 & $3: 43: 12$ & 47.05 & 19.67 & 32 & 80 & 107 & 107 & 33 & 322 & 52 & $\mathrm{D}$ \\
\hline 190 & 1998.09 .29 & $22: 14: 52$ & 44.30 & 20.03 & 183 & 85 & -120 & 65 & 42 & 298 & 33 & D \\
\hline
\end{tabular}




\section{References}

Aki, K. and Richards, P. G.: Quantitative Seismology, Vol. 1, Freeman, San Francisco, 1980.

Ambraseys, N. N. and Melville, C. P.: A History of Persian Earthquakes. First Edition, Cambridge University Press, 1982.

Atkinson, G. M.: Implications of eastern ground motion characteristics for seismic hazard assessment in eastern North America, in: Earthquake Hazards and the Design of Constructed Facilities in the Eastern United States, Annals N.Y.A.S., Vol. 558, 1989.

Bada, G., Cloetingh, S. A. P. L., Gerner, P., and Horváth, F.: Sources of recent tectonic stress in the Pannonian Region: inferences from finite element modelling, Geophys. J. Int. 134, 87-101, 1998.

Bada, G.: Cenozoic stress field evolution in the Pannonian Basin and surrounding orogens. Inferences from kinematic indicators and finite element stress modelling, PhD thesis, Vrije Universiteit Amsterdam, 204 p, 1999.

Bada, G., Horváth, F., Fejes, I., and Gerner, P.: Review of the prentday geodynamics of the Pannonian Basin: progress and problems, J. Geodynamics, 27, 501-527, 1999.

Badawy, A., Horváth, F., and Tóth, L.: Source parameters and tectonic interpretation of recent earthquakes (1995-1997) in the Pannonian Basin, J. Geodynamics, 31, 87-103, 2001.

Bisztricsány, E.: On the problem of magnitude determination, Zeitschr. f. Geophys., Bd. 24, 153-160, 1958.

Csomor, D. and Kiss, Z.: Die Seismizität von Ungarn, Studia Geophysica et Geodetica, 33-42, 1959.

Csomor, D.: Determination of stresses acting at the focus of the Hungarian earthquake of January 12, 1956. Annal. Univ. Sci. Budapest, Sect. Geol. (in Russian), 10, 3-8, 1966.

Fara, H. D.: A new catalogue of earthquake fault plane solutions, Bulletin of Seismological Society of America, 54, 1491-1517, 1964.

Fröhlich, C.: Triangle diagrams: ternary graphs to display similarity and diversity of earthquake focal mechanisms, Physics of the Earth and Planetary Interiors, 75, 193-198, 1992.

Gangl, G.: Seismotectonic investigations of the western part of the inneralpine Pannonian basin (Eastern Alps and Dinarides), XIV. Gen. Ass. of the ESC Trieste, 74, Berlin, 409-410, 1975.

Gerner, P.: Catalogue of Earthquake Focal Mechanism Solutions for the Pannonian Region (42-52 N; 12-28 E), Manuscript, Geophysical Dept., Eötvös Univ., Budapest, p. 39, 1995.

Gerner, P., Bada, G., Dövényi, P., Müller, B., Oncescu, M. C., Cloetingh, S. A. P. L., and Horváth, F.: Recent tectonic stress and crustal deformation in and around the Pannonian basin: data and models, in: Durand, B., Jolivet, L., Horváth, F., and Séranne, M. (Eds.): The Mediterranean basins: Tertiary extension within the Alpine orogen, Geol. Soc. London Spec. Publ. 156, 269-294, 1999.

Gutenberg, B. and Richter, C. F.: Seismicity of the Earth, Princeton, Univ. Press, 300 pp, 1949.

Horváth, F.: Neotectonics of the Pannonian basin and the surrounding mountain belts: Alps, Carpathians and Dinarides. Ann. Geophys., 2/2, 147-154, 1984.

Horváth, F.: Neotectonic behaviour of the Alpine-Mediterranean region, in: Royden, L. H. and Horváth, F. (Eds.): The Pannonian Basin - A study in basin evolution, AAPG Memoir, 45, 49-51, 1988.

Kitaibel, P. and Tomtsányi, A.: Dissertatio de terrae motu in genere, ac in specie Mórensi anno 1810, die 14, januarii orto, Buda, p. $110,1814$.
Mónus, P., Tóth, L., and Zsíros, T.: Focal mechanisms of Central European Earthquakes, XXI. General Assembly of ESC, Sofia, Bulgaria, 1988.

Müller, B., Wehrle, V., and Fuchs, K.: The 1997 release of the World Stress Map, 1997. (available on-line at http://www-wsm. physik.uni-karlsruhe.de/pub/Re197/wsm97.html)

Oncescu, M. C.: Deep structure of the Vrancea region, Romania, inferred from simultaneous inversion for hypocentres and 3D velocity structures, Ann. Geophys., 2, 23-28, 1984.

Oncescu, M. C.: On the Stress Tensor in Vrancea Region, Journal of Geophysics, 62, 62-65, 1987.

Ove Arup \& Partners: Engineering for Earthquakes in the Philippines, Seminar document produced by Ove Arup \& Partners, 1990.

Ove Arup \& Partners: UK Seismic Hazard and Risk - A Preliminary Study (3 volumes), Report prepared for the Department of Environment, 1992.

Ove Arup \& Partners: PHARE Regional Programme VVER 440213, Seismic Hazard Re-evaluation, Final Report produced by Ove Arup \& Partners, 1995.

Pleidell, A.: A magyar várostörténet első fejezete, Századok (in Hungarian), 68, 158-200, 1934.

Réthly, A.: The earthquakes of the Carpathian Basins (456-1918). Akadémiai Kiadó, Budapest, p. 510, 1952.

Richter, C. F.: An Instrumental Earthquake Magnitude Scale, Bulletin of the Seismological Society of America, 25, 1, 1-32, 1935.

Ritsema, A. R.: The Earthquake Mechanisms of the Balkan Region, Survey of the seismicity of the Balkan region, UNDP Project REM/70/172, 36, 1974.

Royden, L. H.: Late Cenozoic tectonics of the Pannonian basin system, in: Royden, L. H. and Horváth, F. (Eds.): The Pannonian Basin - A study in basin evolution, AAPG Memoir, 45, 27-48, 1988.

Tóth, L., Mónus, P., and Zsíros, T.: The Berhida (Hungary) earthquake of 1985, Gerlands Beitr. Geophysik, 98, 312-321, 1989.

Tóth, L., Mónus, P., and Zsíros, T.: Hungarian Earthquake Bulletin, 1995, GeoRisk, Budapest, p. 69, 1996.

Tóth, L., Mónus, P., and Zsíros, T.: Hungarian Earthquake Bulletin, 1996, GeoRisk, Budapest, p. 67, 1997.

Tóth, L., Mónus, P., and Zsíros, T.: Hungarian Earthquake Bulletin, 1997, GeoRisk, Budapest, p. 68, 1998.

Tóth, L., Csabafi, R., Grenerczy, Gy. , Horváth, F., Kiszely, M., Kosztyu, Z., Kovácsvölgyi, S., Mónus, P., Páncsics, Z., Posgay, K., Ráner, G., Tátrai, M. R., Szabó, Z., Tóth, T., Wéber, Z., and Zsíros, T.: SUMMARY REPORT: Seismic Monitoring of Paks NPP Site, GeoRisk, Budapest, pp. 129, 1998 b.

Tóth, L., Mónus, P., and Zsíros, T.: Hungarian Earthquake Bulletin, 1998, GeoRisk, Budapest, p. 71, 1999.

Tsapanos, T. M.: The seismicity of Greece in comparison with the seismicity of other seismogenic countries of the world, Proc. 1st Symp. on Developments in Seismology and Geophysics in Greece, 1988.

Willmore, P. L.: Manual of Seismological Observatory Practice, World Data Center A for Solid Earth Geophysics, 1979.

Zoback, M. D. and Zoback, M. L.: Tectonic stress field of North America and relative plate motions, in: Slemmons, D. B., Engdahl, E. R., Zoback, M. D., and Blackwell, D. D. (Eds.): The Geology of North America, Decade Map, vol. 1, Neotectonics of North America. GSA, Boulder Colorado, 339-366, 1991.

Zoback, M. L.: First- and second-order patterns of stress in the lithosphere: the World Stress Map Project. Journal of Geophysical Research, 97, 11 703-11 728, 1992. 
Zsíros, T., Mónus, P., and Tóth. L.: Hungarian Earthquake Catalogue (456-1986), MTA GGKI, Budapest, p. 182, 1988.

Zsíros, T.: Focal depth of Hungarian earthquakes. Gerlands Beitr. Geophysik, 98, 146-154, 1989.

Zsíros, T.: Macroseismic focal depth and intensity attenuation in the Carpathian region. Acta Geod. Geoph. Hung., 31, 115-125, 1996.
Zsíros, T.: Seismicity of the Sub-Carpathian region of the northeastern section of the Pannonian Basin. Acta Geod. Geoph. Hung., vol. 35(3), 313-317, 2000a.

Zsíros, T.: A Kárpát-medence szeizmicitása és földrengés veszélyessége: Magyar földrengés katalógus (456-1995), MTA FK GGKI, Budapest, ISBN 9638381159, p. 495, 2000 b. 